\title{
Effect of Ergotamine on Serotonin-Mediated Responses in the Rodent and Human Brain
}

\author{
Nasser Haddjeri, Ph.D, Bernard Seletti, M.D., François Gilbert, M.D., \\ Claude de Montigny, M.D., Ph.D, and Pierre Blier, M.D., Ph.D.
}

In the rat dorsal hippocampus and dorsal raphe nucleus, the microiontophoretic application of ergotamine and 5-HT suppressed the firing activity of $\mathrm{CA}_{3}$ pyramidal neurons and 5-HT neurons, an effect antagonized by selective $5-\mathrm{HT}_{1 \mathrm{~A}}$ receptor antagonists. Co-application of ergotamine prevented the inhibitory action of 5-HT on the firing activity of $\mathrm{CA}_{3}$ pyramidal neurons but not of 5-HT neurons, indicating that ergotamine acted as a partial $5-\mathrm{HT}_{1 \mathrm{~A}}$ receptor agonist in the dorsal hippocampus and as a full agonist at 5-HT $\mathrm{T}_{1 \mathrm{~A}}$ autoreceptors. Ergotamine decreased, in a concentration-dependent manner, the electrically evoked release of $\left[{ }^{3} \mathrm{H}\right] 5-\mathrm{HT}$ in preloaded rat and guinea pig hypothalamus slices; this effect was prevented by the nonselective 5-HT receptor antagonist methiothepin but not by the selective 5-HT $\mathrm{T}_{1 B / 1 D}$ receptor antagonist GR 127935 or the $\alpha_{2}$-adrenoceptor antagonist idazoxan. Although body temperature in humans remained unchanged following inhaled ergotamine, in the rat, subcutaneously injected ergotamine produced a hypothermia that was prevented by a pretreatment with the 5-HT $\mathrm{H}_{1 \mathrm{~A} / 1 \mathrm{~B}}$ receptor $/ \beta$-adrenoceptor antagonist pindolol. Finally in humans, ergotamine did not alter prolactin or adrenocorticotropic hormone levels, but increased growth hormone level, which was prevented by pindolol. Cortisol level was increased in humans by ergotamine, but this enhancement was unaltered by pindolol. In conclusion, the present results suggest that ergotamine acted in the rat brain as a $5-\mathrm{HT}_{1 A}$ receptor agonist and as an agonist of terminal 5-HT autoreceptor of a yet undefined subtype. In humans, ergotamine also displayed some $5-\mathrm{HT}_{1 \mathrm{~A}}$ receptor activity but, probably because of lack of receptor selectivity, it did not present the same profile as other $5-\mathrm{HT}_{1 A}$ receptor agonists.

[Neuropsychopharmacology 19:365-380, 1998]

(C) 1998 American College of Neuropsychopharmacology. Published by Elsevier Science Inc.
KEY WORDS: Ergotamine; Serotonin, 5-HT $\mathrm{HA}_{1 \mathrm{~A}}$ receptors; Dorsal raphe; Dorsal hippocampus; Body temperature; Hormonal responses

Ergotamine (12'-hydroxy-2'-menthyl-5' $\alpha$-(phenyl-methyl) ergotaman- $3^{\prime}, 6^{\prime}, 18$-trione) is a medication commercially available for the treatment of migraine and cluster

From the Neurobiological Psychiatry Unit (NH, BS, CM, PB), McGill University, Department of Psychiatry, Montréal, Québec, Canada; and the Département d'Endocrinologie (FG), Hôpital Maisonneuve-Rosemont, Montréal, Québec, Canada.

Address correspondence to: N. Haddjeri, Ph.D., Neurobiological Psychiatry Unit, McGill University Department of Psychiatry, 1033 Pine Avenue West, Montréal, Québec, Canada H3A 1A1.

Received November 20, 1997; revised January 21, 1998; accepted, March 4, 1998. headache (Tfelt-Hansen and Johnson 1993; Silberstein and Young 1995). Although it has affinity for $\alpha$-adrenergic and dopaminergic receptors (Goodman and Gilman 1985; Badia et al. 1988), it is generally believed to exert its antimigraine effect via serotonin (5-HT) receptors. Indeed, this drug has a high affinity for nearly all subtypes of 5-HT receptors. In particular, it is one of the rare compounds with a subnanomolar affinity for $5-\mathrm{HT}_{1 \mathrm{~A}}$ receptors (Langer and Schoemaker 1986; see Silberstein 1997 for review). It is also noteworthy that ergotamine is a high-affinity ligand for the recently cloned 5-HT binding sites $5-\mathrm{HT}_{5}, 5-\mathrm{HT}_{6}$, and 5- $\mathrm{HT}_{7}$ (Erlander et al. 1993; Lovenberg et al. 1993; Boess and Martin 1994). Because a clear physiological function has yet to be linked to these sites, ergotamine might, thus, be a useful tool to investigate the putative role of these 5 -HT receptors. 
In the present studies, the effect of ergotamine on 5-HT responses, which are mediated by different 5-HT receptor subtypes, was studied in the rodent and human brain. In a first series of experiments, the effect of microiontophoretic application of ergotamine was examined in vivo on the firing activity of rat dorsal raphe 5-HT neurons and of dorsal hippocampus $\mathrm{CA}_{3}$ pyramidal neurons to assess its intrinsic activity at the pre- and postsynaptic $5-\mathrm{HT}_{1 \mathrm{~A}}$ receptors. The capacity of ergotamine to modify the electrically evoked release of $\left[{ }^{3} \mathrm{H}\right] 5-$ HT from preloaded hypothalamus slices prepared from rats and guinea pigs was then determined to estimate its activity at the terminal 5-HT autoreceptors, which exert a negative feedback influence on 5-HT release. Although these are generally believed to be of the $5-\mathrm{HT}_{1 \mathrm{~B}}$ subtype in the rat and of the $5-\mathrm{HT}_{1 \mathrm{D}}$ subtype in the guinea pig/human brain, recent data suggest that another 5-HT receptor subtype may be involved in inhibiting 5-HT release from 5-HT terminals (Piñeyro et al. 1995). In a third series of experiments, the effect of ergotamine on lowering rat body temperature was studied to verify the capacity to activate $5-\mathrm{HT}_{1 \mathrm{~A}}$ receptors mediating this hypothermic effect. In a final series of experiments carried out in humans, the capacity of ergotamine to modify body temperature and plasma prolactin, cortisol, growth hormone, and adrenocorticotropic hormone $(\mathrm{ACTH})$ was assessed given that some $5-\mathrm{HT}_{1 \mathrm{~A}}$ receptor agonists can alter these parameters in humans (Lesch et al. 1990a,b,c; Miller et al. 1990; Benkelfat 1993; Seletti et al. 1995; Shiah et al. 1997).

\section{MATERIALS AND METHODS}

The electrophysiological experiments were carried out in male Sprague-Dawley rats, weighing 250 to $300 \mathrm{~g}$, kept under standard laboratory conditions (12:12 lightdark cycle with free access to food and water), and anesthetized with chloral hydrate $(400 \mathrm{mg} / \mathrm{kg}$, IP). Supplemental doses were given to maintain the constant anesthesia and to prevent any nociceptive reaction to a tail pinch.

\section{Recordings from $\mathrm{CA}_{3}$ Dorsal Hippocampus Pyramidal Neurons}

Recording and microiontophoresis were performed with five-barrelled glass micropipettes broken back to 8 to $12 \mu \mathrm{m}$ under microscopic control (ASI Instruments, Warren, MI, USA). The central barrel was filled with a $2 \mathrm{M}$ $\mathrm{NaCl}$ solution and used for extracellular unitary recording. The pyramidal neurons were identified by their large amplitude $(0.5-1.2 \mathrm{mV})$ and long-duration (0.8$1.2 \mathrm{~ms}$ ) simple spikes alternating with complex spike discharges (Kandel and Spencer 1961). The side barrels contained the following solutions: 5-HT creatinine sulphate $(20 \mathrm{mM}$ in $200 \mathrm{mM} \mathrm{NaCl}, \mathrm{pH} 4)$, ergotamine (1 $\mathrm{mM}, \mathrm{pH} 3.8)$, quisqualic acid (1.5 $\mathrm{mM}$ in $200 \mathrm{mM} \mathrm{NaCl}$, $\mathrm{pH}$ 8), BMY 7378 (50 mM in $200 \mathrm{mM} \mathrm{NaCl}, \mathrm{pH}$ 3), or 2 $\mathrm{M} \mathrm{NaCl}$ used for automatic current balancing. The rats were mounted in a stereotaxic apparatus, and the microelectrodes were lowered at $4.2 \mathrm{~mm}$ lateral and 4.2 anterior to lambda into the $\mathrm{CA}_{3}$ region of the dorsal hippocampus. Because most hippocampus pyramidal neurons are not spontaneously active under chloral hydrate anesthesia, a small current of quisqualate $(+1$ to $1-8$ nA) was used to activate them within their physiological firing range (10-15 Hz; Ranck 1975). The suppressant effect of 5-HT is unaltered by the level of activation of the neurons (Brunel and de Montigny 1987). Neuronal responsiveness to the microiontophoretic application of 5-HT and ergotamine were assessed by determining the number of spikes suppressed per nanoampere. The duration of the microiontophoretic applications of the agonists was $50 \mathrm{~s}$. The same ejection current of 5-HT (2-8 $\mathrm{nA}$ ) and ergotamine (10-30 nA) was always used before and during application of the $5-\mathrm{HT}_{1 \mathrm{~A}}$ receptor antagonists BMY 7378 (5-10 nA; Chaput and de Montigny 1988) and WAY 100135 (1 mg/kg; Fletcher et al. 1994). The same ejection current of 5-HT was also used before and during ergotamine (10-30 nA).

\section{Recordings of Dorsal Raphe 5-HT Neurons}

Microiontophoresis was performed with five-barrelled micropipettes (R \& D Scientific glass Co., Spencerville, $\mathrm{MD}$, USA) preloaded with fiberglass filaments in order to facilitate filling, and the tip was broken back to 4 to 8 $\mu \mathrm{m}$. The central barrel was used for recording and filled with a $2 \mathrm{M} \mathrm{NaCl}$ solution. The side barrels contained the following solutions: 5-HT creatinine sulphate (5 $\mathrm{mM}$ in $200 \mathrm{mM} \mathrm{NaCl}, \mathrm{pH} 4)$, ergotamine $(1 \mathrm{mM}, \mathrm{pH}$ 3.8), quisqualic acid (1.5 mM in $200 \mathrm{mM} \mathrm{NaCl}, \mathrm{pH}$ 8), and $2 \mathrm{M} \mathrm{NaCl}$ used for automatic current balancing. The rats were placed in a stereotaxic frame, and a burr hole was drilled on midline $1 \mathrm{~mm}$ anterior to lambda. Dorsal raphe 5-HT neurons were encountered over a distance of $1 \mathrm{~mm}$ starting immediately below the ventral border of the aqueduct of Sylvius. These neurons were identified using the criteria of Aghajanian (1978): a slow $(0.5-2.5 \mathrm{~Hz})$ and regular firing rate and a longduration $(0.8-1.2 \mathrm{~ms})$ positive action potential. The responsiveness of 5-HT neurons to 40-s microiontophoretic applications of 5-HT (1-5 nA) and ergotamine (1-10 nA) was always assessed using the same ejection current prior to and following the intravenous injection of the selective $5-\mathrm{HT}_{1 \mathrm{~A}}$ receptor antagonist WAY 100635 (1 mg/kg; Fletcher et al. 1996); the same ejection current of 5-HT (1-5 nA) was also used before and during ergotamine application (1-10 nA). 


\section{Superfusion Experiments in Brain Slices}

Male Sprague-Dawley rats (250-300 g) or Hartley guinea pigs (300-400 g) were killed by decapitation and their brains rapidly removed and dissected on an ice-cold glass plate. Slices from the hypothalamus of $0.4-\mathrm{mm}$ thickness were prepared using a Mcllwain chopper and incubated for $30 \mathrm{~min}$ at $37^{\circ} \mathrm{C}$ in Krebs solution containing $20 \mathrm{~nm}\left[{ }^{3} \mathrm{H}\right] 5-\mathrm{HT}$ creatinine sulphate (specific activity $914 \mathrm{GBq} / \mathrm{mmol}$; NEN Research Products, Mississauga, ON, Canada) and bubbled with a mixture of $95 \%$ $\mathrm{O}_{2}-5 \% \mathrm{CO}_{2}$. The composition of the Krebs solution in mmol/l concentration was $\mathrm{NaCl} 118, \mathrm{KCl} 4.7, \mathrm{CaCl}_{2} 1.3$, $\mathrm{MgCl}_{2} 1.2, \mathrm{NaH}_{2} \mathrm{PO}_{4} 1, \mathrm{NaHCO}_{3} 25$, glucose 11.1, EDTA 0.004 , and ascorbic acid 0.11. At the end of the incubation period with $\left[{ }^{3} \mathrm{H}\right] 5-\mathrm{HT}$, one rat or guinea pig hypothalamus slice was placed into each of the glass chambers and superfused continuously at a rate of $0.5 \mathrm{ml} /$ min with Krebs solution maintained at $37^{\circ} \mathrm{C}$ and saturated with $\mathrm{O}_{2} / \mathrm{CO}_{2}$. The slices were superfused $60 \mathrm{~min}$ before the first stimulation (S1). The two periods of electrical stimulation were delivered $8 \mathrm{~min}$ (S1) and $44 \mathrm{~min}$ (S2) after the end of the washing period (360 pulses: 2 $\mathrm{ms}, 20$ or $30 \mathrm{~mA}$ at $3 \mathrm{~Hz}$ for $2 \mathrm{~min}$ ). Ergotamine (0.1 to $100 \mathrm{nM}$ ) was added $20 \mathrm{~min}$ before S2 and maintained in the superfusion medium until the end of the experiments. The amounts of tritium released per 4 min sample was expressed as a fraction of the total tritium content of the slices at the onset of the 19 consecutive fractions collected starting $52 \mathrm{~min}$ after the beginning of superfusion. At the end of the experiments, the slices were solubilized in $0.5 \mathrm{ml}$ of Soluene 350 (Packard Instruments, Downers Grove, IL, USA), and the radioactivity in the slices and the samples was determined by liquid scintillation spectrometry. For either rat and guinea pig hypothalamus slices, the nonselective 5-HT receptor antagonist methiothepin (300 $\mathrm{nM}$ and $1 \mu \mathrm{M})$, the selective 5- $\mathrm{HT}_{1 \mathrm{~B} / 1 \mathrm{D}}$ receptor antagonist GR 127935 (300 nM) or the $\alpha_{2}$-adrenoceptor antagonist idazoxan (1 $\mu \mathrm{M}$ ) was added $20 \mathrm{~min}$ before S1 and maintained in the superfusion medium until the end of the experiments. The electrically evoked overflow of tritium was calculated as the total increase in radioactivity above basal outflow (sp1 or sp2) obtained in the sample preceding the stimulation and expressed as the ratio S2/S1. The $\mathrm{sp} 2 / \mathrm{sp} 1$ ratios were calculated in order to determine whether the drugs modified the basal outflow of tritium.

\section{Effect of Ergotamine on Rat Body Temperature}

Male Sprague-Dawley rats (200 to $250 \mathrm{~g}$ ) were kept in individual cages in a room at stable temperature of $23^{\circ} \mathrm{C}$ for $1 \mathrm{~h}$ before the experiments. Body temperature was measured by inserting a lubricated probe $3 \mathrm{~cm}$ into the rectum while lightly restrained. The readings were obtained with a digital thermometer (TM99A, Harvard apparatus, South Natick, MA, USA), and the experimenter was blind to the treatments. The readings of the temperature were obtained every $30 \mathrm{~min}$ after the IP injection of ergotamine $(0.125,0.5$ or $2 \mathrm{mg} / \mathrm{kg})$; whereas, the $5-\mathrm{HT}_{1 \mathrm{~A} / 1 \mathrm{~B}}$ receptor/ $\beta$-adrenoceptor antagonist pindolol (10 mg/ $\mathrm{kg}, \mathrm{SC})$ was injected $30 \mathrm{~min}$ before ergotamine administration. Five rats were used in each group.

\section{Effect of Ergotamine on Hormone Plasma Levels and Body Temperature in Humans}

Healthy male volunteers were recruited through local newspaper advertisements. All potential research subjects underwent physical and psychiatric examinations (using the Structured Clinical Interview for DSM-III-R, nonpatient version, Spitzer et al. 1992) had an electrocardiogram and routine laboratory tests, including serum sequential multiple analysis, complete blood count, thyroid function tests, HIV test, hepatitis virus tests, urine analysis, and a urine toxicology screen for drug abuse. Only physically healthy subjects without a personal history of psychiatric illness or a family history of mood disorders or alcoholism in first-degree relatives were invited to participate. Subjects scoring two or more on at least three symptoms on the Hopkins Symptom Checklist (HSC-90) and more than three on the Beck Inventory for depression were excluded. All subjects were medication free for a minimum of 2 weeks prior to testing, smoking fewer than 10 cigarettes per day, and ingested no more than the equivalent of five beers per week and three cups of coffee per day. This study was approved by the Research Ethics Board of the Department of Hospital Maisonneuve-Rosemont. Written informed consent was obtained from all subjects before enrollment in the study. In a randomized, double-blind, $3 \times 3$ Latin square design, 12 subjects received an oral placebo followed $2 \mathrm{~h}$ later by a placebo inhalant, an oral placebo followed $2 \mathrm{~h}$ later by three puffs of ergotamine (for a total of $1 \mathrm{mg}$ ), $30 \mathrm{mg}$ pindolol orally followed $2 \mathrm{~h}$ later by three puffs of ergotamine on a double-blind basis. Ergotamine and the placebo inhalants were administered using an aerochamber device to improve absorption. Blood samples for measuring hormone plasma levels were collected in ice-cold plastic tubes containing $10 \mu \mathrm{l} / \mathrm{ml}$ of $0.5 \mathrm{M} \mathrm{Na}_{2}$ EDTA. They were centrifuged $\left(20 \mathrm{~min}\right.$ at $2,500 \mathrm{~g}$ at $\left.4^{\circ} \mathrm{C}\right)$ within 1 hour of sampling. Plasma was aliquoted into plastic tubes and stored at $-70^{\circ} \mathrm{C}$ until time of assay. Plasma prolactin, growth hormone, and adrenocorticotropic hormone (ACTH) levels were determined by standard immunoradiometric assays using commercially available kits (Immunocorp, Montréal, PQ; ICN Biomedicals, Montréal, PQ; Nichols Institute Diagnositics, San Juan Capistrano, CA, USA). Plasma cortisol was determined by radioimmunoassay using a commercially available kit (Kallestad, Austin, TX, USA). The inter- 
and intra-assay coefficients of variation were as follow: prolactin $=3.9$ and $2.4 \%$; growth hormone $=12.1$ and $12.3 \%$; $\mathrm{ACTH}=7.8$ and $3.2 \%$; and cortisol $=7.6$ and $8.4 \%$. At the end of the study, all measurements were carried out in one assay by a technician blind to the order and nature of drug treatments. Sublingual body temperature was measured using a thermistor probe (Electro-therm, model TM99A), and digital readings were obtained at the end of a 2-min recording period, and three sessions were carried out at least 1 week apart.

\section{Statistical Analysis}

All data are expressed as mean \pm SEM unless specified otherwise. Statistical comparison between groups were carried out by using either two-tailed or paired Student's $t$-test, and either the two way analysis of variance (ANOVA) and simple effects were subsequently analyzed using a student's Newman-Keuls test or the Dunnett's Method. In humans, ANOVA was used to confirm that there were no significant differences between the treatment groups at baseline. The results of the study were submitted to analysis of covariance for repeated measures, appropriate to the Latin-square design, with the baseline value as covariate (Fleiss 1986).

Drugs. The following drugs were used: ergotamine tartrate (Research Biochemicals, Natick, MA, USA); 5-HT creatinine sulphate, quisqualic acid, idazoxan $\mathrm{HCl}$ (Sigma Chemical Co., St. Louis, MO, USA); BMY 7378 (Bristol Myers Co., Evansville, IN, USA), WAY 100135, WAY 100635 (Wyeth Research, Berkshire, UK); GR 127935 (Glaxo Research, Greenford, UK); ( \pm ) pindolol (Aldrich Chemical Company, Milwaukee, WI, USA for use in rats and for human use: Visken ${ }^{\circledR}$, Sandoz, Canada); methiothepin maleate (Hoffman-LaRoche, Montréal, PQ). The concentrations and the doses used for these compounds were chosen on the basis of previous successful experiments carried out in our and other laboratories.

\section{RESULTS}

\section{Effects of 5-HT and Ergotamine on the Firing Activity of Dorsal Hippocampus $\mathrm{CA}_{3}$ Pyramidal Neurons}

It has been previously demonstrated that 5-HT microiontophoretically applied on the rat dorsal hippocampus pyramidal neurons induces an inhibitory effect on the firing activity, which is mediated by postsynaptic $5-\mathrm{HT}_{1 \mathrm{~A}}$ receptors (Chaput and de Montigny 1988; Blier and de Montigny 1987). For all the $\mathrm{CA}_{3}$ hippocampus pyramidal neurons tested, 5-HT (2-8 nA) and ergotamine (10-30 nA) induced a marked reduction of firing activity, generally from 30 to $80 \%$ (Figure 1A). This inhibitory effect occurred in the absence of alteration of the shape of the action potentials and was current-dependent. The intravenous injection of the $5-\mathrm{HT}_{1 \mathrm{~A}}$ receptor antagonist WAY 100135 (1 mg/kg), which decreased slightly by itself the firing activity of $\mathrm{CA}_{3}$ pyramidal neurons, markedly reduced the inhibitory action of both 5-HT and ergotamine (Figure 1A,B). The mean suppressant action of 5-HT and ergotamine on the firing activity of $\mathrm{CA}_{3}$ pyramidal neurons is represented in the Figure 1B. WAY 100135 significantly reduced by $29 \%$ the suppressant effect of 5-HT and by $45 \%$ that of ergotamine. To determine whether this antagonistic effect was caused by a local or distant action, the $5-\mathrm{HT}_{1 \mathrm{~A}}$ receptor antagonist BMY 7378 (Chaput and de Montigny 1988) was applied directly by microiontophoresis. Although BMY 7378 also reduced by itself the firing activity of pyramidal neurons, the suppressant action of 5-HT and ergotamine on $\mathrm{CA}_{3}$ pyramidal neurons firing activity was also reduced by the concomitant application of BMY 7378 (5-10 nA, Figure 2A,B). As exemplified in Figure 2, for $\mathrm{CA}_{3}$ pyramidal neurons, concomitant ejection of $\mathrm{BMY}$ 7378 reduced the inhibitory action of 5-HT and of ergotamine by 62 and $41 \%$, respectively. It has been previously shown that the partial $5-\mathrm{HT}_{1 \mathrm{~A}}$ receptor agonists gepirone and tandospirone antagonize the suppressant effect of 5-HT on hippocampus pyramidal neurons firing activity (Blier and de Montigny 1990; Godbout et al. 1991). In the present study, the concomitant microiontophoretic application of ergotamine (10-30 nA) also antagonized the reducing effect of 5-HT on the firing rate of $\mathrm{CA}_{3}$ pyramidal neurons (Figure $3 \mathrm{~A}, \mathrm{~B}$ ), thus revealing its partial $5-\mathrm{HT}_{1 \mathrm{~A}}$ agonistic property at the postsynaptic level.

\section{Effects of 5-HT and Ergotamine on the Firing Activity of Dorsal Raphe 5-HT Neurons}

The firing activity of the dorsal raphe 5-HT neurons was reduced, in a dose-dependent manner, by microiontophoretic applications of 5-HT (1-5 nA) and ergotamine (1-6 nA). As exemplified in Figure 4A, ergotamine did not antagonize the inhibitory action of 5-HT on the firing activity of dorsal raphe 5-HT neurons. In contrast with the results obtained in the $\mathrm{CA}_{3}$ region of the hippocampus, ergotamine did not attenuate the inhibitory effect of 5-HT (Figure 4B), thus showing its full 5- $\mathrm{HT}_{1 \mathrm{~A}}$ agonistic property at the 5-HT autoreceptors. Moreover, the inhibitory effect of both 5-HT and ergotamine microiontophoretically applied onto dorsal raphe 5-HT neurons were antagonized by the selective $5-\mathrm{HT}_{1 \mathrm{~A}}$ receptor antagonist WAY 100635 (1 mg/kg, IV, Figure 5A,B), although at this dose, WAY 100635 markedly, but transiently, decreased by itself the firing activity of 5 -HT neurons. WAY 100635 significantly reduced by 82 $\%$ the suppressant effect of $5-\mathrm{HT}$ and by $53 \%$ that of ergotamine. 


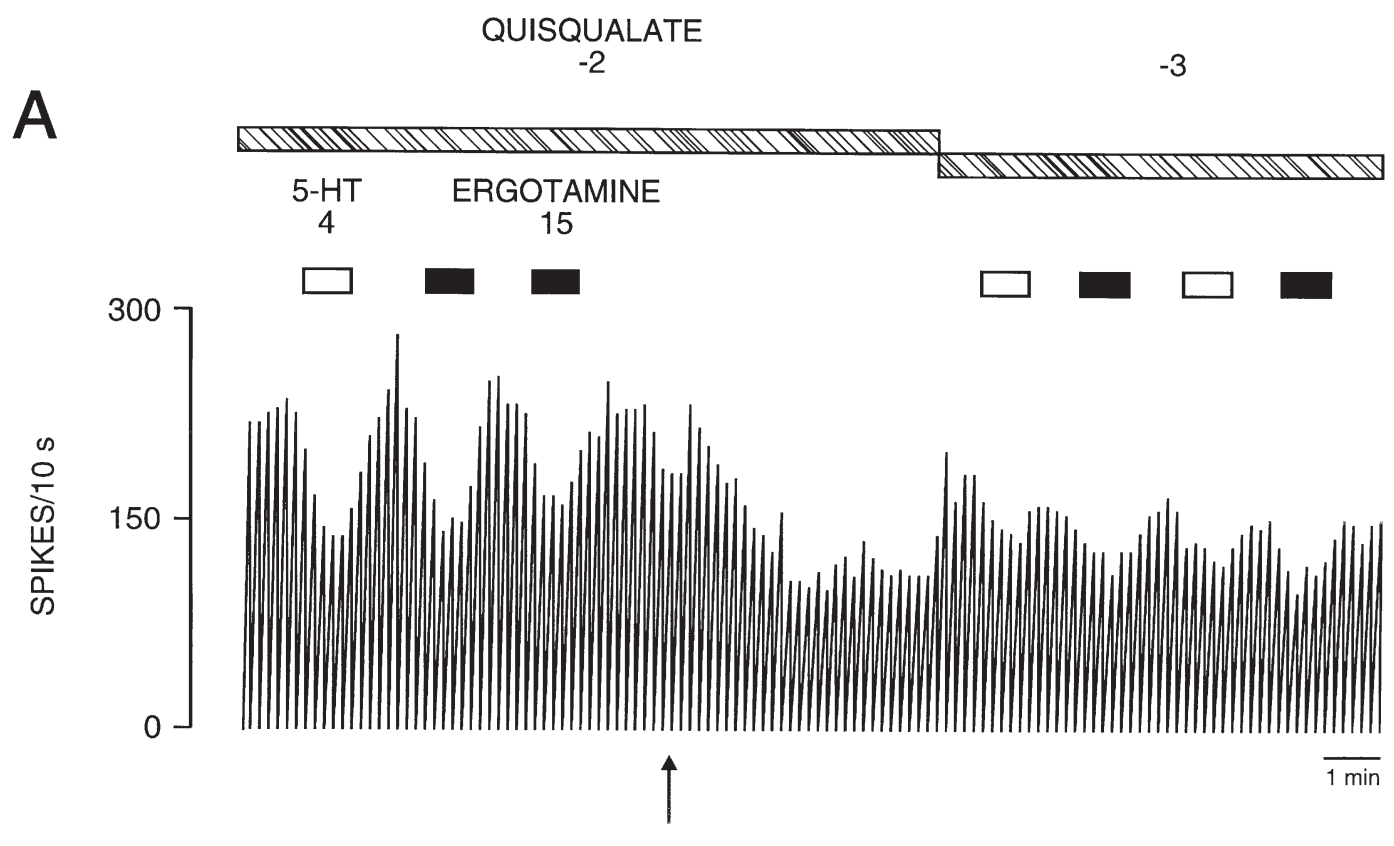

(+) WAY 100135

( $1 \mathrm{mg} / \mathrm{kg}$, i.v.)

B

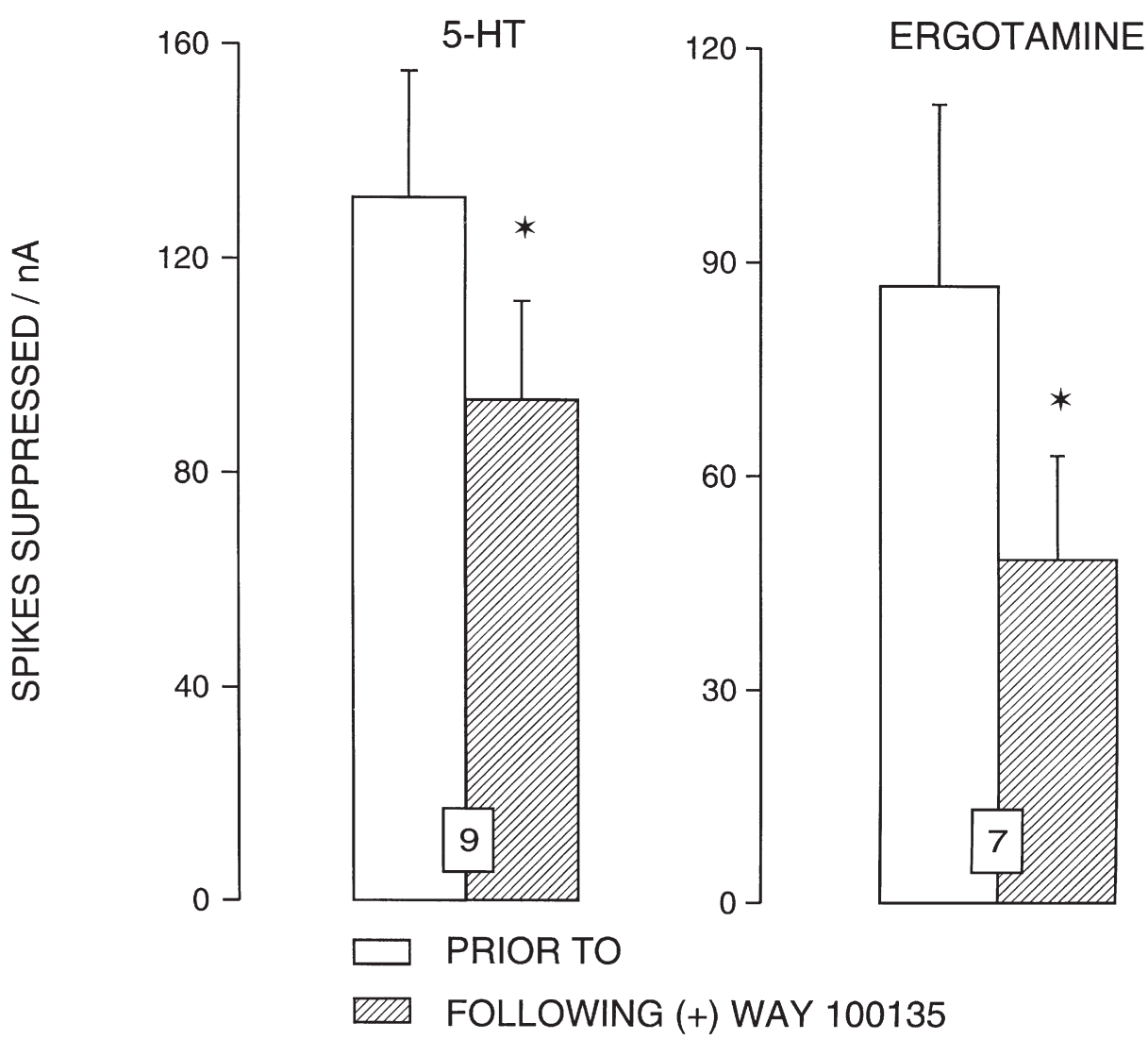

Figure 1. A. Integrated firing rate histogram of a dorsal hippocampus $\mathrm{CA}_{3}$ pyramidal neuron showing its responsiveness to microiontophoretic application of 5-HT and ergotamine before and after the subsequent injection of WAY $100135(1 \mathrm{mg} / \mathrm{kg})$. This neuron was activated with a quisquilate ejection current of $-2 \mathrm{nA}$. Horizontal bars indicate the duration of the applications for which the current is given in nanoamperes. In panel B, the responsiveness to 5-HT and ergotamine is expressed as the number of spikes suppressed per nanoampere. The number in the control column indicates the number of neurons per rats tested. ${ }^{*} p<.05$ (paired Student's $t$-test). 


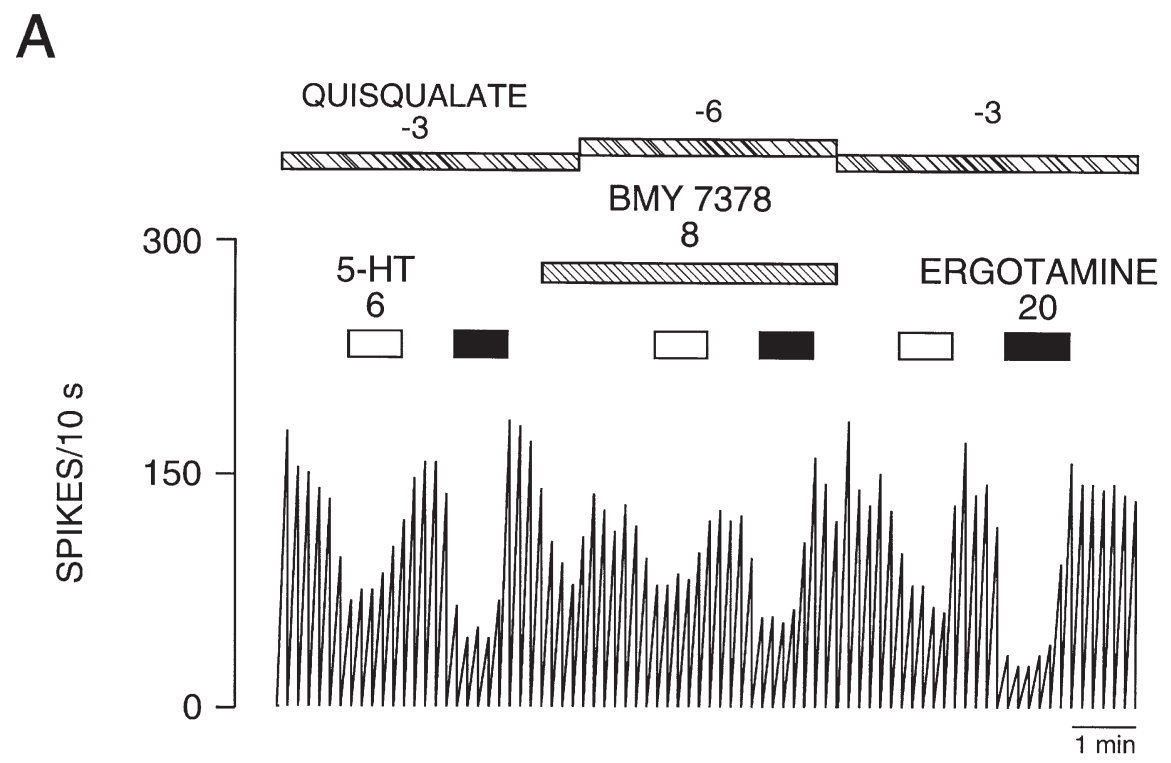

B

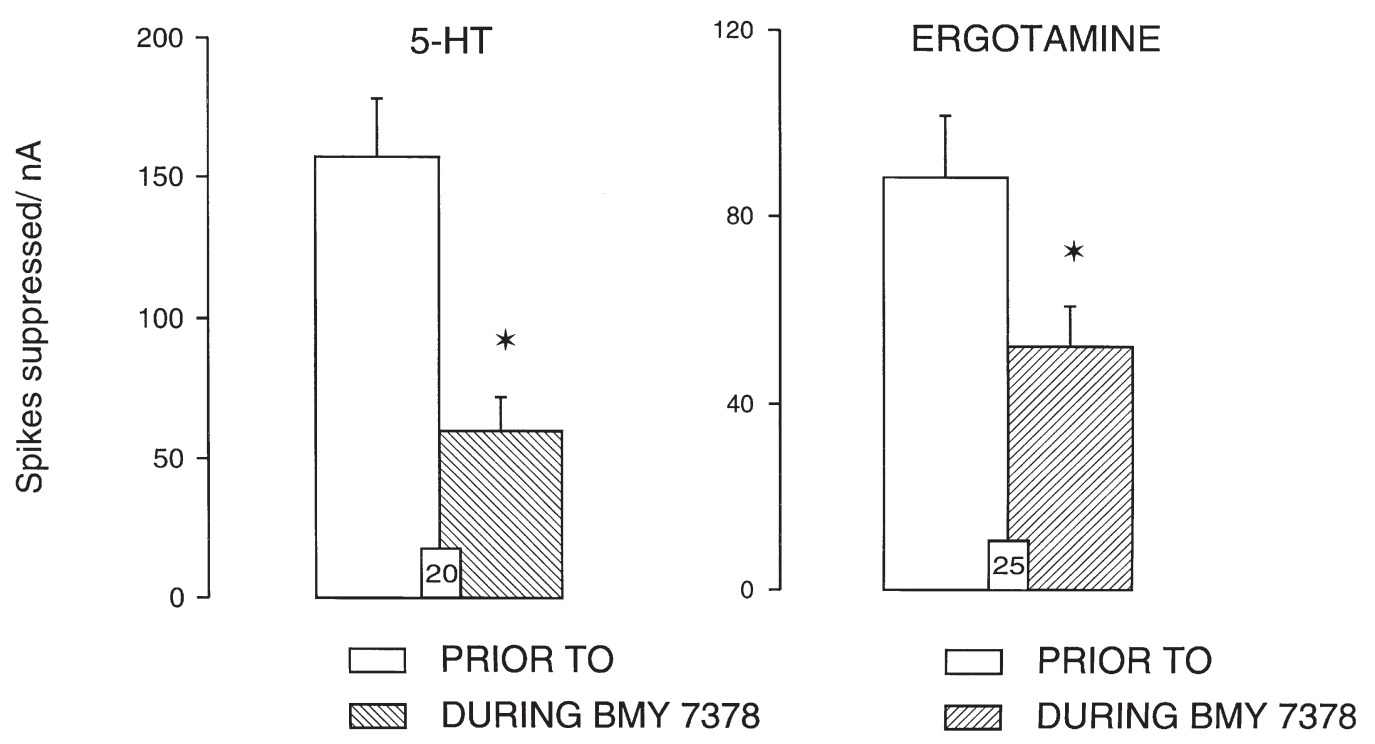

Figure 2. Integrated firing rate histogram of a dorsal hippocampus $\mathrm{CA}_{3}$ pyramidal neuron showing its responsiveness to microiontophoretic application of 5-HT and ergotamine before and during the concomitant ejection of BMY 7378 (A). The bars indicate the duration of application for which the ejection currents are given in nanoamperes. In panel $\mathbf{B}$, the responsiveness to 5-HT and ergotamine is expressed as the number of spikes suppressed per nanoampere, the number in the columns indicates the number of neurons tested and 4 to 5 neurons were assessed per rat. * $p<.05$ (paired Student's $t$-test).

\section{Superfusion Experiments in Brain Slices}

The electrically evoked $\left[{ }^{3} \mathrm{H}\right]-5-\mathrm{HT}$ release in rat hypothalamus slices was decreased in a concentration-dependent manner when ergotamine was added $8 \mathrm{~min}$ before S2 (Figure 6A), without altering the spontaneous out- flow of radioactivity (data not shown). As illustrated in Figure $6 \mathrm{~A}$, when the 5- $\mathrm{HT}_{1 \mathrm{~B} / 1 \mathrm{D}}$ receptor antagonist GR $127935(0.3 \mu \mathrm{M})$ was added to the superfusion medium 20 min before S1 until the end of the experiment, it did not attenuate the reducing effect of 1 and $100 \mathrm{nM}$ of er- 

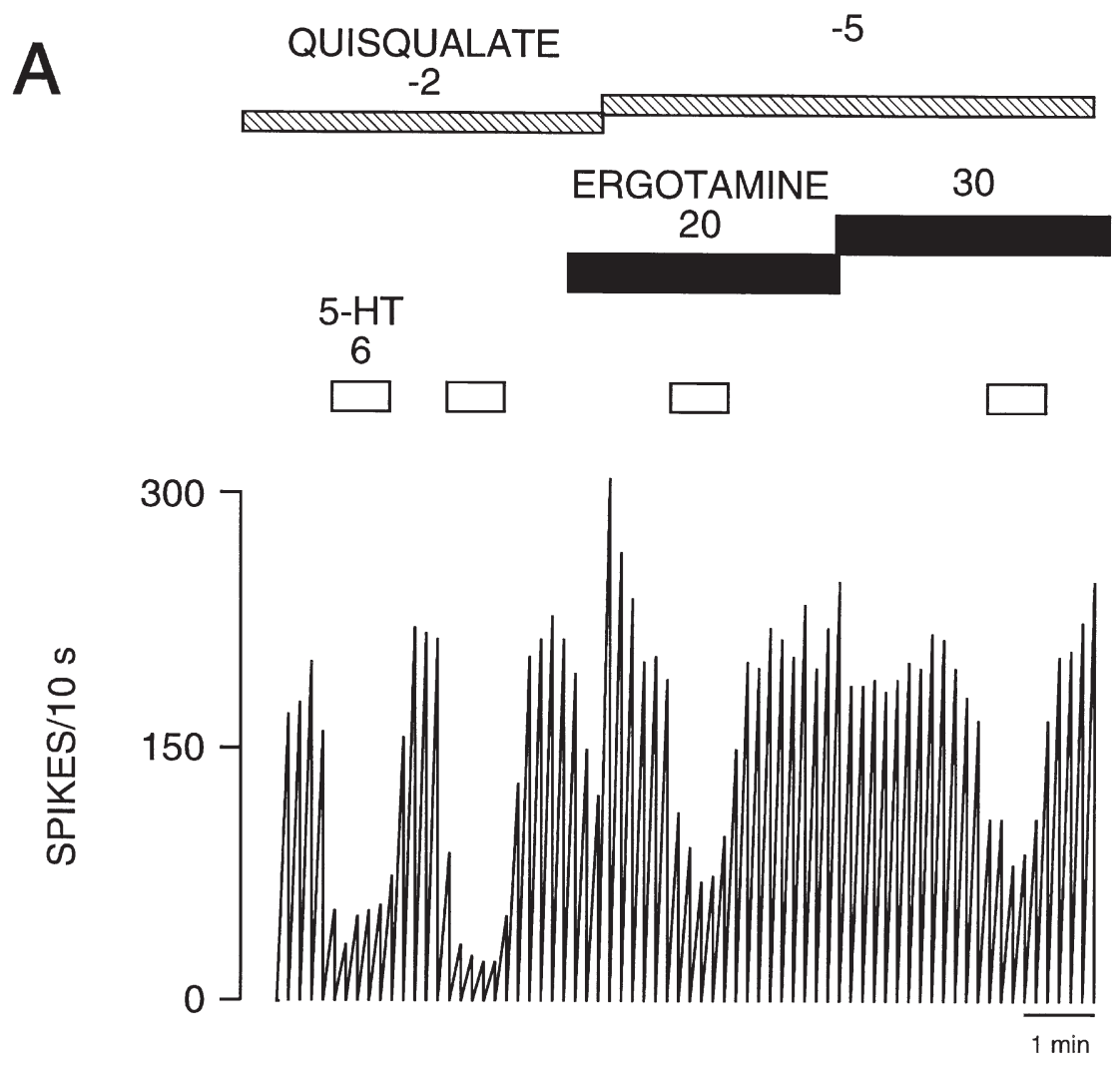

B

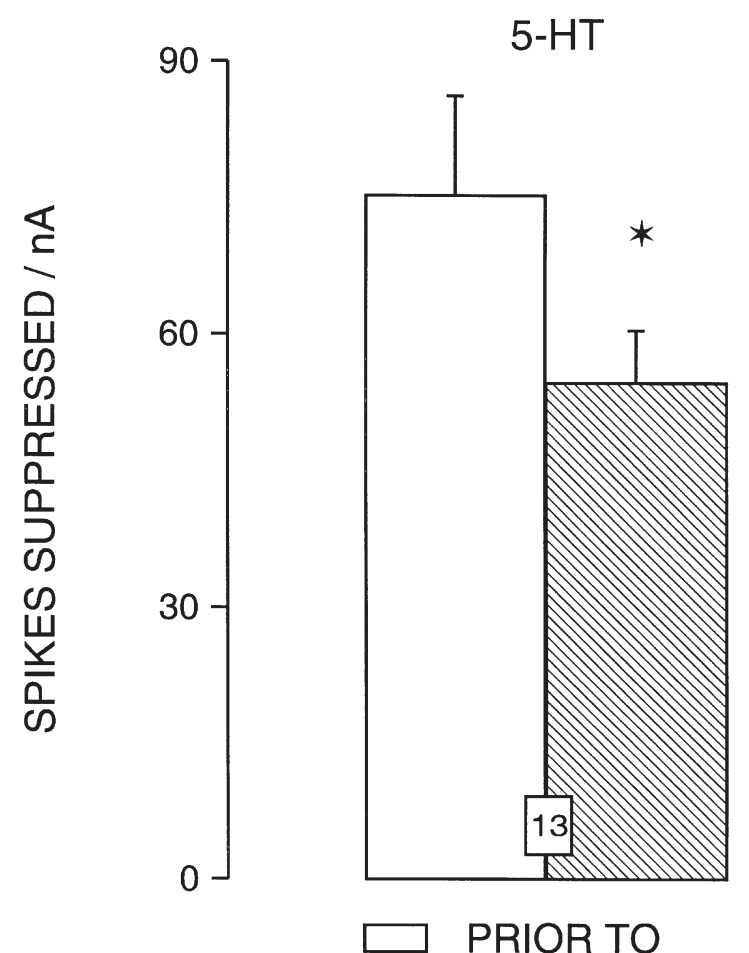

DUVING ERGOTAMINE
Figure 3. Intergrated firing rate histogram of a dorsal hippocampus $\mathrm{CA}_{3}$ pyramidal neuron showing its responsiveness to microiontophoretic application of 5-HT before and during the concomitant ejections of ergotamine (A). This neuron was activated with a quisquilate ejection current of -2 to -5 $\mathrm{nA}$. The bars indicate the duration of application for which the ejection currents are given in nanoamperes. In panel $\mathbf{B}$, the responsiveness to $5-\mathrm{HT}$ is expressed as the number of spikes suppressed per nanoamper. The number in the columns indicates the number of neurons tested and 3 to 4 neurons were assessed per rat. The mean suppressant effect of 5-HT was expressed before and during ergotamine. ${ }^{*} p<.05$ (paired Student's $t$-test). gotamine on the evoked $\left[{ }^{3} \mathrm{H}\right]-5-\mathrm{HT}$ overflow in hypothalamus slices. In guinea pig slices, ergotamine also decreased in a concentration-dependent manner the electrically evoked release of $\left[{ }^{3} \mathrm{H}\right]-5-\mathrm{HT}$ (Figure 6B). GR
$127935(0.3 \mu \mathrm{M})$, added $20 \mathrm{~min}$ before S1 and maintained in the superfusate, did not modify the 1 and 100 $n M$ of ergotamine-induced decrease of evoked $\left[{ }^{3} \mathrm{H}\right]-5-$ HT overflow. In contrast, when the nonselective 5-HT 

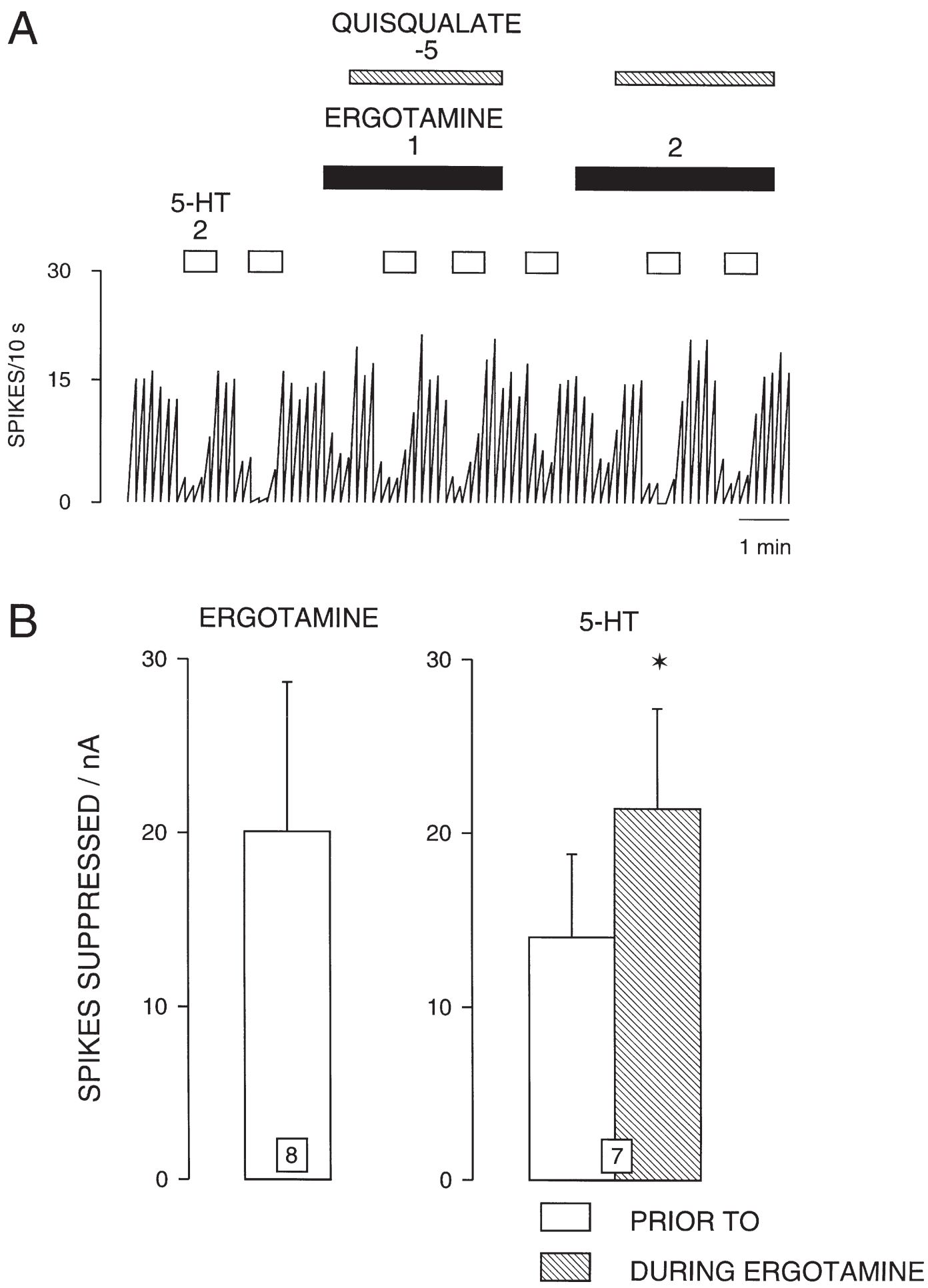

Figure 4. Integrated firing rate histogram of a dorsal raphe 5-HT neuron showing its responsiveness to microiontophoretic application of 5-HT before and after the ejection of ergotamine (A). Horizontal bars indicate the duration of the applications for which the currents are given in nanoampers. In panel B, the means suppressant effect of ergotamine alone (left) and that of 5-HT (right) was expressed before and during ergotamine. The number in the columns indicates the number of neurons tested and 2 to 3 neurons were assessed per rat. * $p<.05$ (two-tailed Student's $t$-test).

receptor antagonist methiothepin $(0.3$ or $1 \mu \mathrm{M})$ was added to the superfusion medium $20 \mathrm{~min}$ before S1, the reducing effect of ergotamine (1-100 $\mathrm{nM})$ on the evoked $\left[{ }^{3} \mathrm{H}\right]-5-\mathrm{HT}$ overflow in both guinea pig and rat hypothal- amus slices was prevented (Figure 6A,B). Because methiothepin and ergotamine are endowed with $\alpha_{2}$-adrenergic properties and $\alpha_{2}$-adrenergic heteroreceptors on 5-HT terminals exert an important effect on 5-HT release, 


\section{A}

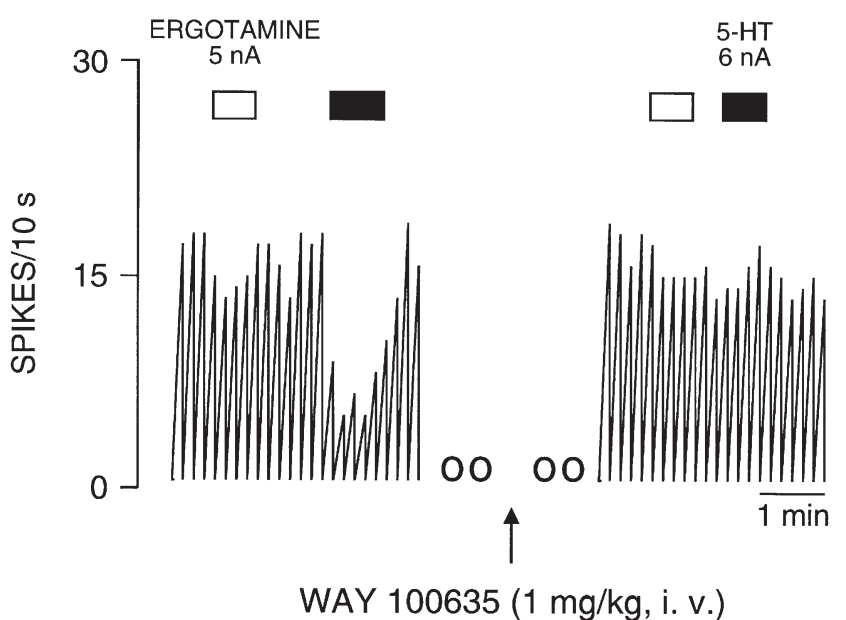

B
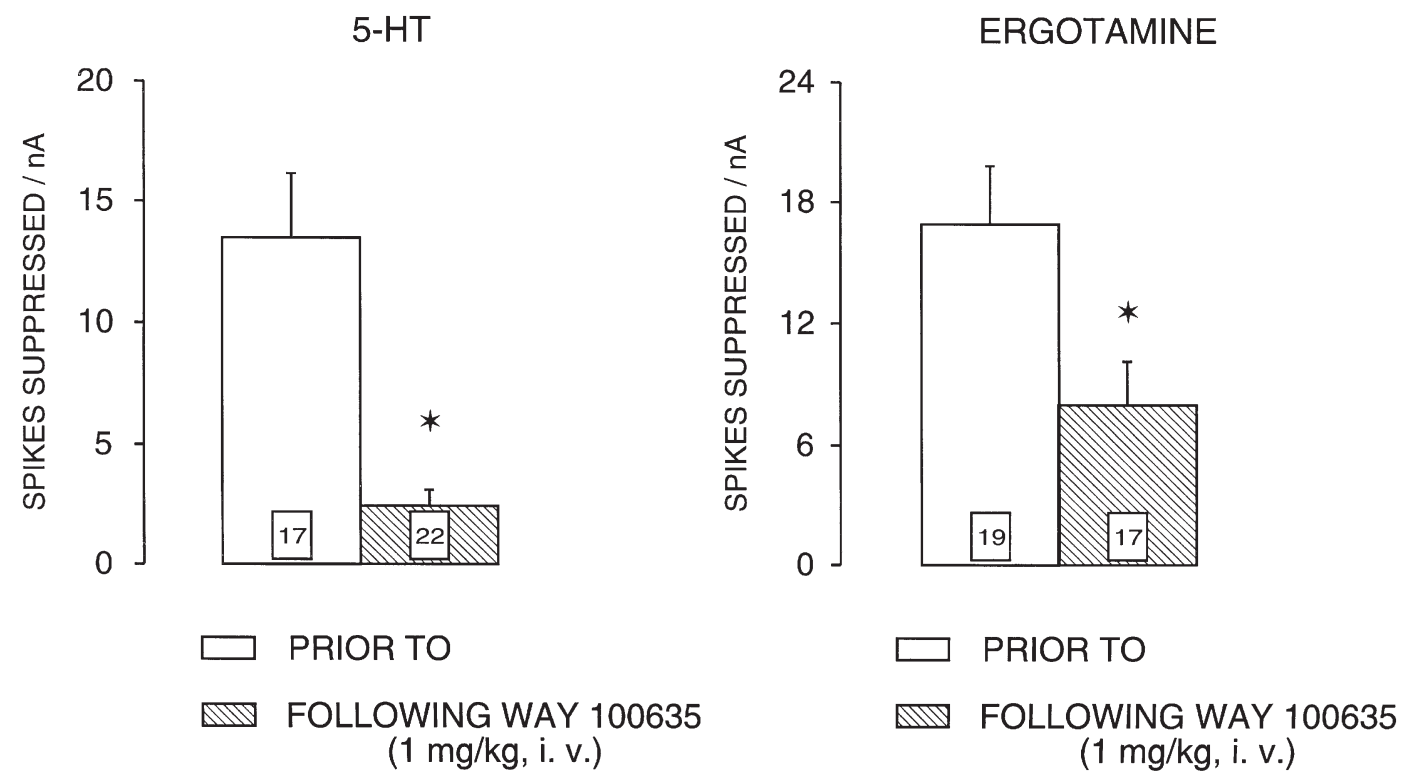

Figure 5. Integrated firing rate histograms of two dorsal raphe 5-HT neurons showing its responsiveness to microiontophoretic application of 5-HT and ergotamine before and after the injection of WAY 100635 ( $1 \mathrm{mg} / \mathrm{kg}$, IV). Horizontal bars indicate the duration of the applications for which the currents are given in nanoamperes. Note the altered effectiveness of 5-HT and ergotamine to suppress firing activity after administration of WAY 100635. In panel B, the responsiveness to 5-HT and ergotamine is expressed as the number of spikes suppressed per nanoampere. The number in the columns indicates the number of neurons tested and 3 to 4 neurons were assessed per rat. ${ }^{*} p<.05,{ }^{* *} p<.01$ (using two-tailed Student's $t$-test).

the capacity of the $\alpha_{2}$-adrenceptor antagonist idazoxan to modify the effect of ergotamine was assessed. When idazoxan $(1 \mu \mathrm{m})$ was added to the superfusion medium $20 \mathrm{~min}$ before $\mathrm{S} 1$ until the end of the experiment, it did not attenuate the reducing effect of $10 \mathrm{nM}$ of ergotamine on the evoked $\left[{ }^{3} \mathrm{H}\right]-5-\mathrm{HT}$ overflow in both guinea pig and rat hypothalamus slices (in rats: without idazoxan: S2/S1 = $0.38 \pm 0.05, n=17$, with idazoxan: S2 $/ \mathrm{S} 1=0.13 \pm 0.05$, $n=5$; in guinea pigs: without idazoxan: S2/S1 $=0.47 \pm$ $0.05, n=13$, with idazoxan: S2/S1 $=0.43 \pm 0.04, n=5$ ). 

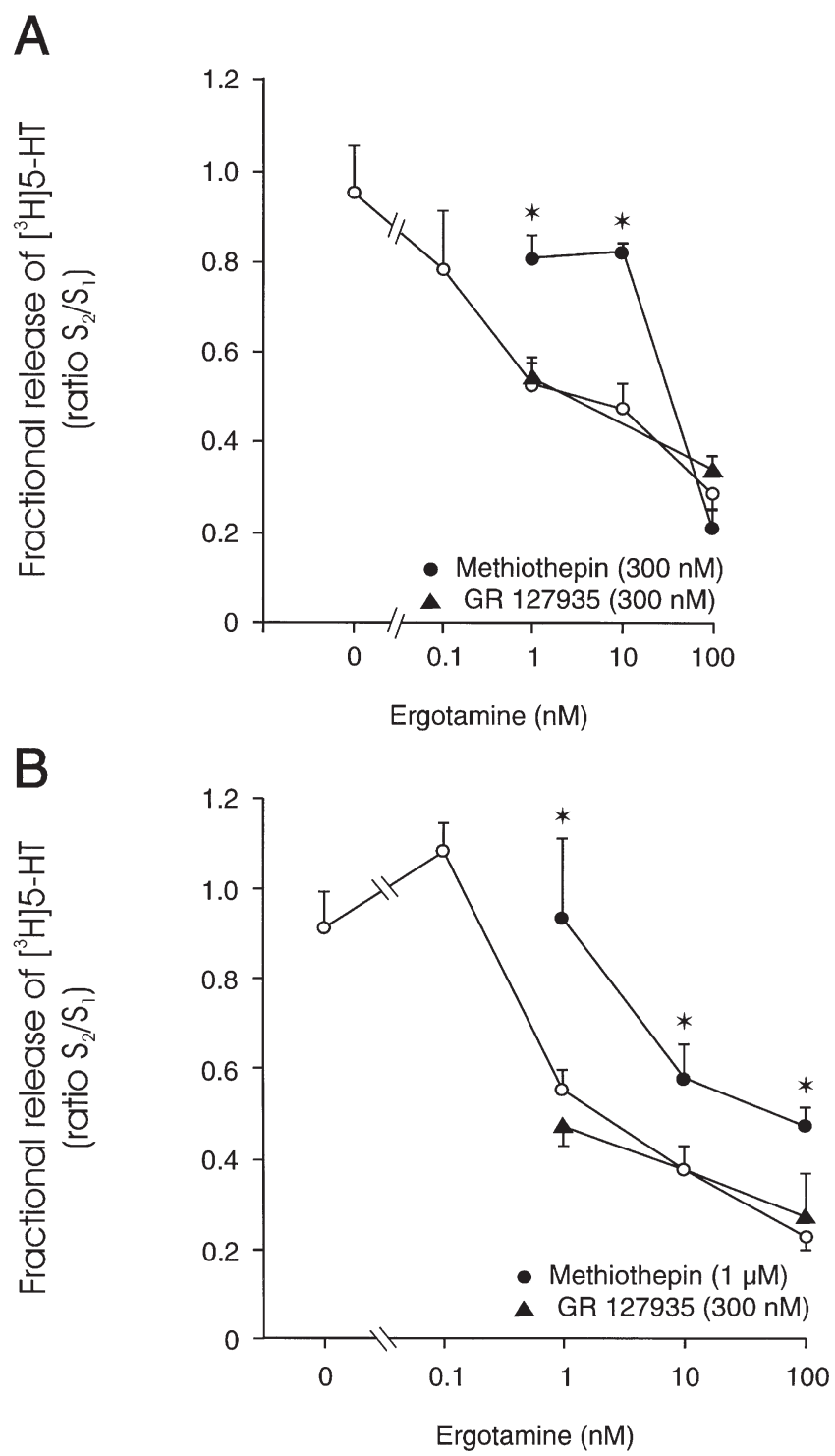

Figure 6. Effect of ergotamine on the release of tritium induced by the electrical stimulation of rat (A) and guineapig (B) hypothalamus slices preloaded with [ $\left.{ }^{3} \mathrm{H}\right]-5-\mathrm{HT}$. Ordinate: fraction of the total tissue radioactivity released by 360 pulses ( $30 \mathrm{~mA}, 2 \mathrm{~ms}, 3 \mathrm{~Hz}$ ) expressed as the ratio S2/S1 (stimulation with ergotamine versus without). GR 127935 or methiothepin were introduced $20 \mathrm{~min}$ before S1 until the end of the superfusion, and ergotamine was introduced 20 min before S2. Each point represents the mean \pm SEM (vertical bars) of 5 to 20 experiments. There was no significant attenuation of the inhibitory effect of ergotamine by GR 127935 ( $p>.05$ using two-tailed Student $t$-test). There was a significant shift to the left of the inhibitory effect or ergotamine by methiothepin ( $p<.05$ as determined by ANOVA).

\section{Effect of Ergotamine on Body Temperature and Hormonal Responses}

In the present study, $0.125 \mathrm{mg} / \mathrm{kg}$, IP of ergotamine produced a rapid hypothermia with a maximal re- sponse $30 \mathrm{~min}$ after its injection, followed by a progressive recovery (Figure 7A). On the other hand, $0.5 \mathrm{mg} /$ $\mathrm{kg}$, IP of ergotamine induced a marked decrease of body temperature with maximal effect $180 \mathrm{~min}$ after its injection (Figure 7A). Similar result was obtained with 2 $\mathrm{mg} / \mathrm{kg}$, IP of ergotamine (Figure 7B). As demonstrated by several investigators, the $5-\mathrm{HT}_{1 \mathrm{~A}}$ receptor agonistinduced hypothermia was prevented by prior administration of the $5-\mathrm{HT}_{1 / 2}$ receptor antagonist methysergide or the $5-\mathrm{HT}_{1 \mathrm{~A} / 1 \mathrm{~B}}$ receptor $/ \beta$-adrenoceptor antagonist pindolol (Aulakh et al. 1988; Wozniak et al. 1988; Hadrava et al. 1995). In the present study, pindolol (10 $\mathrm{mg} / \mathrm{kg}, \mathrm{IP}$ ) administered $30 \mathrm{~min}$ before ergotamine (2 $\mathrm{mg} / \mathrm{kg}$, SC) prevented the hypothermic action of ergotamine, thus suggesting a $5-\mathrm{HT}_{1 \mathrm{~A}}$-mediated hypothermia response of ergotamine (Figure 7B). On the other hand, neither the administration of ergotamine alone nor after pindolol pretreatment modified the oral temperature in humans (Figure 7C), and pindolol by itself did not significantly modify the human body temperature (data not shown).

The 1-mg dose of ergotamine, whether administered alone or with pindolol, did not alter the plasma levels of prolactin or ACTH (Figure 8A,D). In contrast, this dose of ergotamine significantly increased growth hormone (interaction [treatment $\times$ time]; Wilks's $\mathrm{F}_{6.17}=2.82, p=$ $.004)$ and cortisol (interaction [treatment $\times$ time]; Wilks's $\left.\mathrm{F}_{6.17}=22.55, p<.001\right)$ levels, but only the growth hormone response was prevented by a pindolol pretreatment (interaction [treatment $\times$ time]; Wilks's $\mathrm{F}_{6.17}=4.74, p<.005$ ) (Figure 8B,C).

\section{DISCUSSION}

At the presynaptic level, the results of the present experiments indicate that ergotamine inhibits the firing activity of rat dorsal raphe 5-HT neurons via the activation of 5- $\mathrm{HT}_{1 \mathrm{~A}}$ autoreceptors. As for all exogenous $5-\mathrm{HT}_{1 \mathrm{~A}}$ receptor agonists thus far tested, ergotamine acted as a full agonist at the somatodendritic $5-\mathrm{HT}_{1 \mathrm{~A}}$ autoreceptor, because when co-applied onto raphe neurons, it did not attenuate the inhibitory effect of the endogenous agonist 5-HT. In fact, the suppressant effect of 5-HT was even greater in the presence of ergotamine. In intracellular recording experiments, it was demonstrated that the ergot derivative lysergic acid diethylamide (LSD) exerts a greater degree of membrane hyperpolerization of 5-HT neurons that 5-HT itself (Aghajanian and Lakoski 1984). Thus, it is possible that ergotamine exerts the same biological effect as its ergot congener LSD on $5-\mathrm{HT}_{1 \mathrm{~A}}$ autoreceptors.

At the postsynaptic level, the suppressant effect of ergotamine on the firing activity of $\mathrm{CA}_{3}$ pyramidal neurons was attributable to the activation of the $5-\mathrm{HT}_{1 \mathrm{~A}}$ receptors. Different $5-\mathrm{HT}_{1 \mathrm{~A}}$ receptor antagonists were 

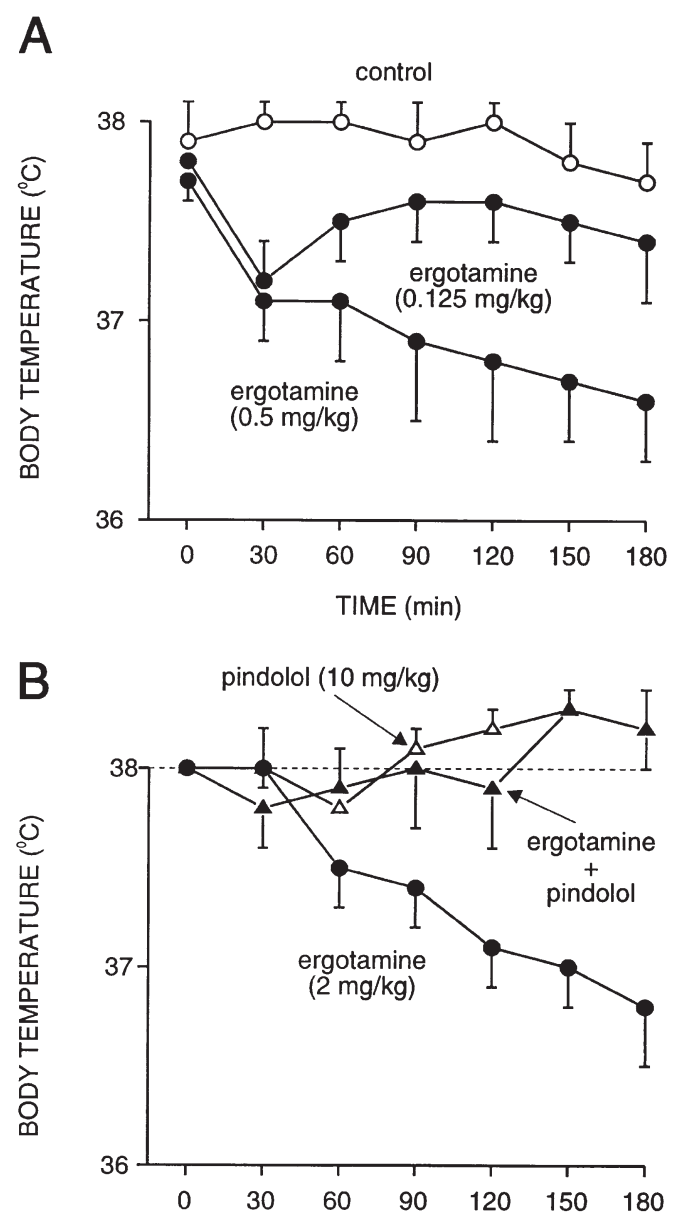

TIME (min)

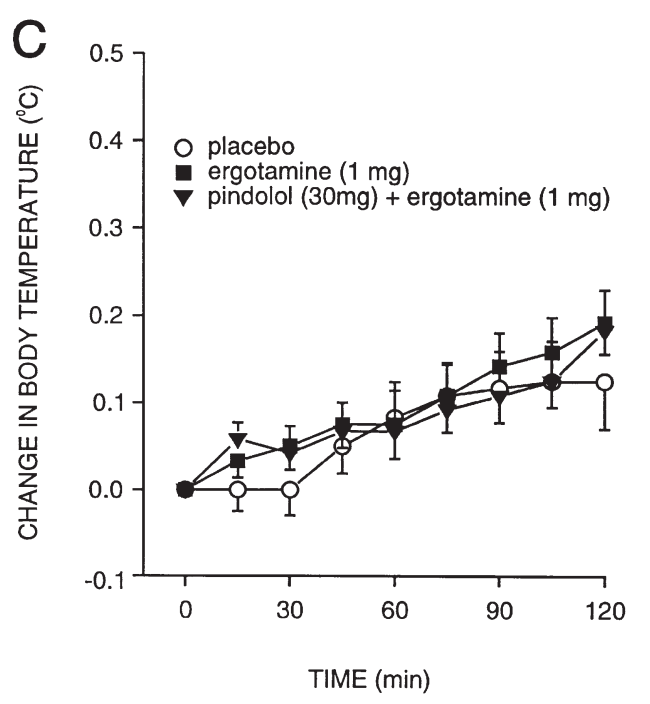

Figure 7. Effect of ergotamine on rectal temperature in rats following its injection at time zero. Each point represents the mean temperature $\left({ }^{\circ} \mathrm{C}\right) \pm$ SEM obtained from 5 animals. Effect of saline versus ergotamine: $p<.05$ as determined by ANOVA (A). In panel B, effects of ergotamine and of the $5-\mathrm{HT}_{1 \mathrm{~A}}$ receptor antagonist pindolol $(10 \mathrm{mg} / \mathrm{kg}, \mathrm{IP})$ injected $30 \mathrm{~min}$ prior to zero on the hypothermia response to ergota- used for these experiments, because the newer and more potent antagonist WAY 100635 was not available when the experiments on hippocampus neurons were carried out. WAY 100135 antagonized to the same degree the inhibitory effect of 5-HT and ergotamine, consistent with previous obtained results obtained with 5-HT and WAY 100135 (Haddjeri and Blier 1995). Ergotamine acted as a partial agonist on these postsynaptic $5-\mathrm{HT}_{1 \mathrm{~A}}$ receptors, because it produced an attenuation of the inhibitory effect of 5-HT when concomitantly applied through the same micropipette. This type of experiment obviously provides an indirect assessment of the magnitude of neuronal hyperpolarization a substance produces. Nevertheless, previous results obtained using this extracellular recording approach have been fully consistent with those obtained using direct measurement of membrane hyperpolarization in in vitro slice preparation (Andrade and Nicoll 1987; Blier et al. 1990). Among several 5- $\mathrm{HT}_{1 \mathrm{~A}}$ receptor agonists thus far tested using the present experimental paradigm, ergotamine is the compound that has an intrinsic activity at postsynaptic hippocampus $5-\mathrm{HT}_{1 \mathrm{~A}}$ receptors similar to gepirone and ipsapirone. The following order of activity has been observed: 8-OH-DPAT $(92 \%)>$ flesinoxan $(85 \%)>$ tandospirone $(57 \%)>$ gepirone $(39 \%)>$ ipsapirone $(31 \%) \approx$ ergotamine (29\%) (Blier and de Montigny 1990; Godbout et al. 1991; Hadrava et al. 1995; Dong et al. 1997).

It has been previously demonstrated in vitro and in vivo that the activation of terminal 5-HT autoreceptors decreases the release of 5-HT (Chaput et al. 1986, Göthert and Weinheimer 1979; Blier et al. 1989). In the present study, ergotamine produced a concentrationdependent inhibition of the electrically evoked release of $\left[{ }^{3} \mathrm{H}\right] 5-\mathrm{HT}$ from preloaded hypothalamus slices prepared from rats and guinea pigs. This inhibition suggested that ergotamine could act as a $5-\mathrm{HT}_{1 \mathrm{~B}}$ and a $5-\mathrm{HT}_{1 \mathrm{D}}$ receptor agonist at terminal autoreceptors in the rat and guinea pig brain, respectively. However, the selective and potent $5-\mathrm{HT}_{1 \mathrm{~B} / 1 \mathrm{D}}$ receptor antagonist GR 127935, which in similar experiments blocks the inhibitory effect of 5- $\mathrm{HT}_{1 \mathrm{~B}}$ and 5- $\mathrm{HT}_{1 \mathrm{D}}$ receptor agonists (Piñeyro et al. 1995; El Mansari and Blier 1996), did not prevent the inhibitory effect of ergotamine on evoked $\left[{ }^{3} \mathrm{H}\right] 5-\mathrm{HT}$ release. This inhibitory effect of ergotamine also could not be attributed to the activation of $\alpha_{2}$-adrenergic heterore-

mine. Each point represents the difference of the body temperature $\left({ }^{\circ} \mathrm{C} \pm \mathrm{SEM}\right)$ obtained from 5 animals. The interaction between pindolol and ergotamine was studied by giving pindolol $30 \mathrm{~min}$ before ergotamine, which was given at time 0 . Effect of pretreatment: $p<.05$ as determined by ANOVA. In panel C, the effects in humans of placebo, ergotamine (1 mg, orally) and of pindolol ( $30 \mathrm{mg}$, orally) given $2 \mathrm{~h}$ prior to ergotamine. No difference of treatments are observed. 
A

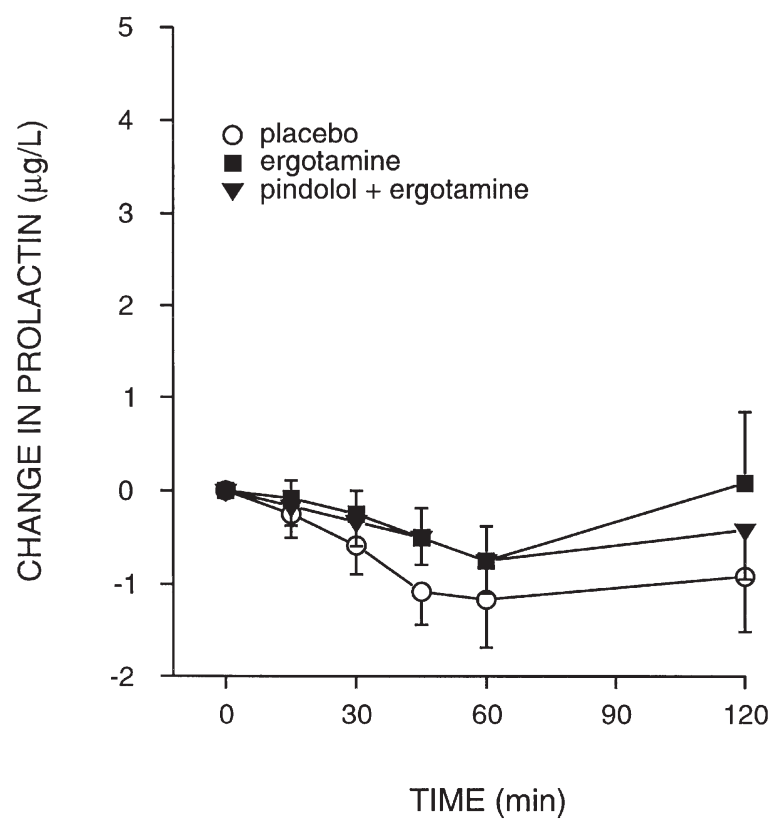

C

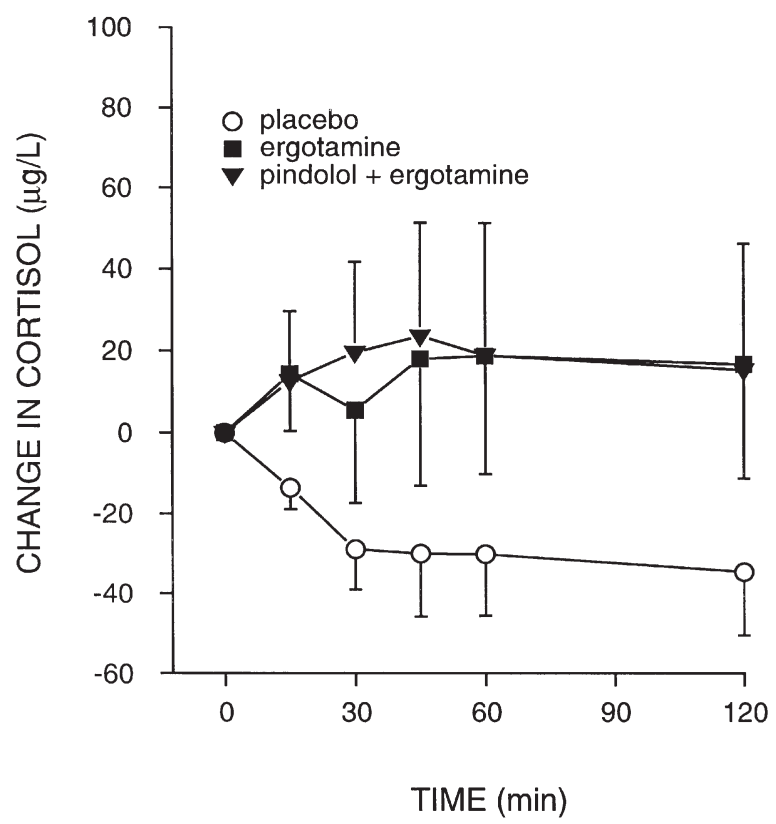

B

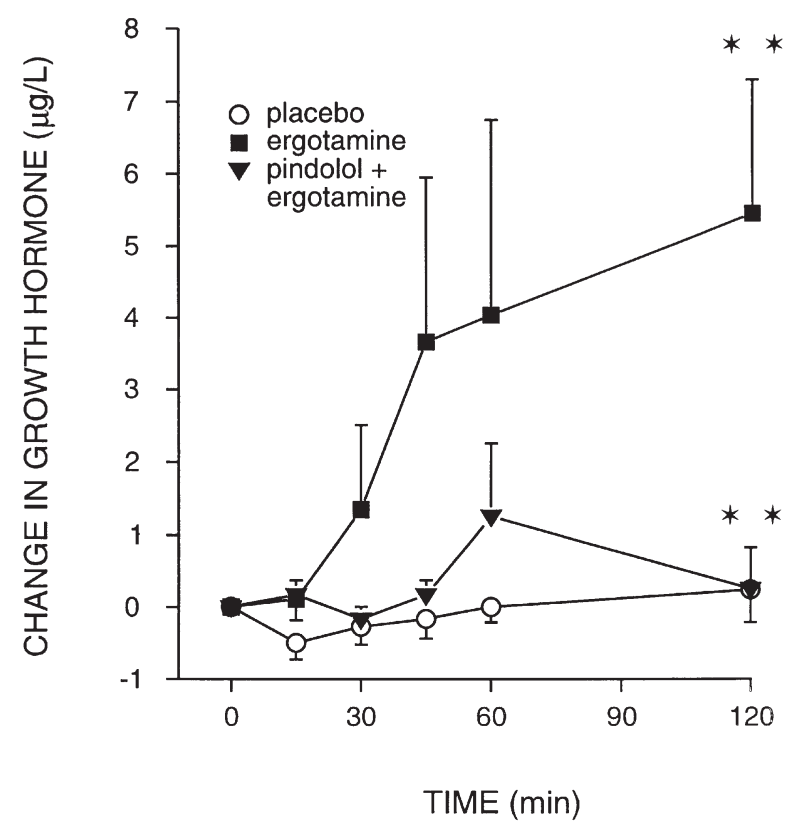

D

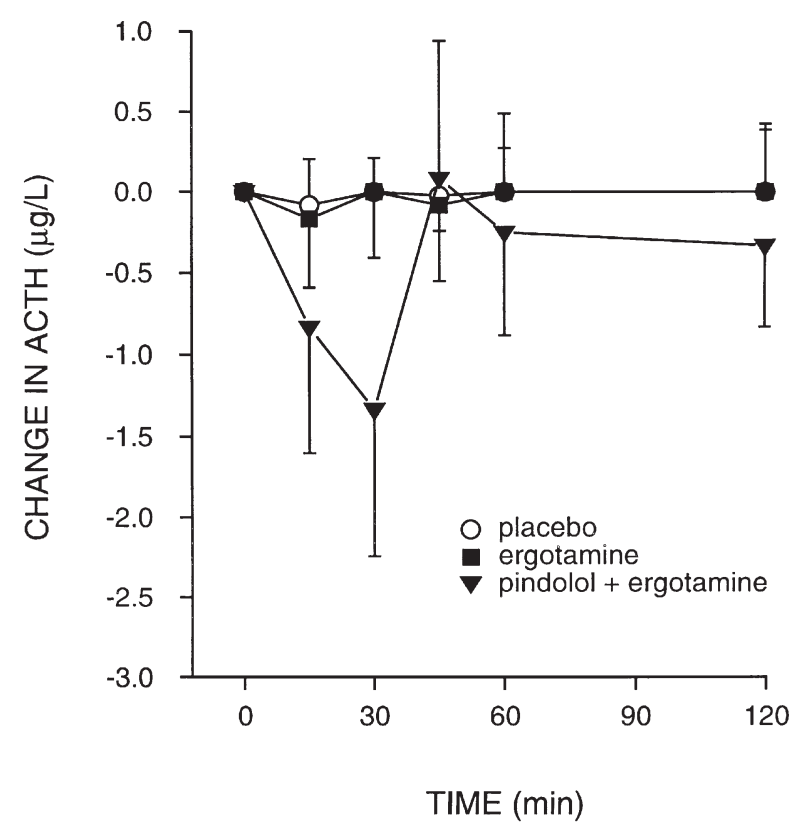

Figure 8. Time-dependent effect of ergotamine, placebo, and pindolol administered $2 \mathrm{~h}$ prior to ergotamine on plasma prolactin (A), growth hormone (B), cortisol (C), and ACTH (D) concentrations. Each point represents mean \pm SEM obtained from 12 healthy volunteers. ${ }^{* *} p<.01$, ergotamine vs. placebo (Wilks's $\mathrm{F}_{1.22}=8.82$ ) and pindolol + ergotamine vs. ergotamine (Wilks's $\left.F_{1.22}=7.07\right)$, ANCOVA.

ceptors, because the potent $\alpha_{2}$-adrenergic antagonist idazoxan did not modify the inhibitory effect of ergotamine. When using the less selective 5-HT receptor antagonist methiothepin, the inhibitory effect of ergotamine was significantly antagonized. From in vitro superfusion studies in hippocampal slices, it is noteworthy that the nonselective 5-HT receptors agonist 5-carboxyamidotryptamine (5-CT) decreases the evoked release of $\left[{ }^{3} \mathrm{H}\right] 5-$ 
HT, and this effect is antagonized by nonselective 5-HT receptor antagonists, such as methiothepin or metergoline a well as the $5-\mathrm{HT}_{1 \mathrm{~A} / 1 \mathrm{~B}}$ receptor antagonist cyanopindolol (Feuerstein et al. 1987; Maura et al. 1987), and other antagonists that possess high affinity for $5-\mathrm{HT}_{1 \mathrm{~B}}$ binding sites. The receptor mediating the inhibitory effect of ergotamine on evoked $\left[{ }^{3} \mathrm{H}\right] 5-\mathrm{HT}$ release, therefore, remains to be identified. There would, indeed, be another 5-CT-sensitive receptor capable of modulating 5 -HT release. It was recently reported that in $5-\mathrm{HT}_{1 \mathrm{~B}}$ receptor knock out mice, the selective $5-\mathrm{HT}_{1 \mathrm{~B}}$ receptor agonist CP 93,129 no longer inhibited the electrically evoked $[\mathrm{H}] 5-\mathrm{HT}$ release in preloaded frontal cortex and hippocampus, as expected, but 5-CT still inhibited the evoked release of $\left[{ }^{3} \mathrm{H}\right]$ 5-HT (Piñeyro et al. 1995). Although methiothepin partially antagonized the inhibitory effect of 5-CT in hippocampus slices from wild type mice, it did not modify that observed in frontal cortex slices from the same animals. Further studies are needed to define the 5-HT receptor subtype involved in the 5-HT-release modulated by ergotamine and 5-CT.

Ergotamine produced a dose-dependent hypothermia in rats when injected systemically. This effect seemed to be maximal at a dose of $0.5 \mathrm{mg} / \mathrm{kg}$, because at a dose of $2 \mathrm{mg} / \mathrm{kg}$, the maximal effect was the same as with $0.5 \mathrm{mg} / \mathrm{kg}$. Furthermore, at the highest dose tested, there was no significant hypothermic effect after $30 \mathrm{~min}$, suggesting that a pharmacological property of ergotamine other than its high affinity for $5-\mathrm{HT}_{1 \mathrm{~A}}$ receptors mediating the hypothermia was reaching a physiological threshold. Previous studies from our laboratories have shown that the administration of the $5-\mathrm{HT}_{1 \mathrm{~A}}$ receptor agonists flesinoxan and $8-\mathrm{OH}-\mathrm{DPAT}$ induce a dose-dependent decrease of the rat body temperature and that the hypothermia induced by flesinoxan was prevented by both pindolol and the $5-\mathrm{HT}_{1 / 2}$ receptor antagonist methysergide, suggesting that the hypothermic response is related to the postsynaptic $5-\mathrm{HT}_{1 \mathrm{~A}}$ receptor activation (Hadrava et al. 1995). It has been proposed that this response is a specific and sensitive index of the activation of the latter receptors (Gudelsky et al. 1988; Millan et al. 1993).

In contrast to buspirone or gepirone, which belong to the azapirone class (Anderson et al. 1990; Anderson and Cowen 1992), ergotamine in humans did not produce a hypothermic effect, as was the case with the response observed in rats (Figure 6). It is noteworthy that the small and gradual increase in body temperature noted following ergotamine administration was also obtained following placebo administration in the same subjects. This was probably more related to ambient temperature rising slightly during testing. This small but consistent increase in body temperature should not, however, have prevented the detection of a difference between placebo and ergotamine. The lack of hypothermic effect of ergotamine in humans may have been caused by an insufficient dose rather than to a lack of receptor specificity for $5-\mathrm{HT}_{1 \mathrm{~A}}$ receptors.

It has been previously shown in humans that $5-\mathrm{HT}_{1 \mathrm{~A}}$ receptor agonists such as flesinoxan, buspirone, ipsapirone, or gepirone increase growth hormone levels (Anderson et al. 1990, Lesch et al. 1989, 1990b; Meltzer et al. 1983; Seletti et al. 1995). It has been suggested that enhancing effect is caused by the activation of a 5-HT receptor, because the stimulatory effect of buspirone on the growth hormone level is unaffected in humans undergoing tryptophan depletion (Blier et al. 1994), and it is blocked by pindolol but not methysergide (Seletti et al. 1995). Given the capacity of ergotamine to enhance growth hormone and its prevention by pindolol, it can be postulated that ergotamine can, indeed, activate human $5-\mathrm{HT}_{1 \mathrm{~A}}$ receptors. Obviously, the activation of monoaminergic receptors other than 5-HT receptors can enhance growth hormone level. These include dopamine $_{2}$ receptors and $\alpha_{2}$-adrenergic receptors for which, however, pindolol does not have significant antagonistic activity (Gundlach et al. 1983; McPherson and Beart 1983). Other neuroendocrine responses were not significantly altered by ergotamine. Such a discrepancy has been noted before between the hypothermic effect of $5-\mathrm{HT}_{1 \mathrm{~A}}$ receptor agonists and neuroendocrine responses. For example, ipsapirone produces a reproducible hypothermic effect in humans; however, it does not increase prolactin levels (Lesch et al. 1989). In contrast, another azapirone, buspirone, produces both a hypothermic effect and a dose-dependent hyperprolactinemia (Cowen et al. 1990; Blier et al. 1994). These differences probably reflect the different pharmacological profiles of these 5- $\mathrm{HT}_{1 \mathrm{~A}}$ receptor agonists. Another possible explanation for these differential responses may also reside in the pharmacological profile of the $5-\mathrm{HT}_{1 \mathrm{~A}}$ receptors themselves. Indeed, in humans, in a recent study carried out with the selective $5-\mathrm{HT}_{1 \mathrm{~A}}$ receptor agonist flexinoxan, the increase in growth hormone, but not in cortisol, was antagonized by the $5-\mathrm{HT}_{1 \mathrm{~A}}$ receptor antagonist pindolol, whereas, the prolactin response was blocked by the nonselective 5-HT receptor antagonist methysergide but not pindolol. These previous experiments with flesinoxan in humans and in rats have also put into evidence species differences. For example, methysergide effectively antagonized flesinoxaninduced hypothermia in humans but not in rats (Hadrava et al. 1995; Seletti et al. 1995). Thus, it is possible that such species differences among $5-\mathrm{HT}_{1 \mathrm{~A}}$ receptors may account for the clear hypothermia produced in rats by ergotamine and its lack of effect in humans. Although previous studies found no change on hormone levels and body temperature after pindolol administration (Lesch et al. 1990d; Anderson and Cowen 1992), the present study in normal volonteers revealed pindolol increases plasma cortisol level and decreases plasma prolactin level, and these results fit well with the recent 
study suggesting that pindolol might act as a partial $5-\mathrm{HT}_{1 \mathrm{~A}}$ receptor agonist in the secretion of cortisol and as an antagonist in the case of the prolactin secretion (Meltzer and Maes 1996).

What was striking with the results obtained with ergotamine in humans was the interindividual variability not noted with intravenous administration of flesinoxan (Seletti et al. 1995). The first possibility to envisage for this variability was the erratic absorption of the drug because of its mode of administration. Despite using an aerochamber, it is impossible that the absorption was irregular. Because blood levels were not determined, it is possible to attribute our results to this factor. In an attempt to avoid this possible pitfall, we have recently carried out a study identical to the present one using intravenous administration of dihydroergotamine and found the same degree of interindividual variability (data not shown). Thus, we must conclude that the differences observed were attributable to the differential responsiveness of various receptor subtypes of the individuals.

In conclusion, these results indicate that ergotamine is an adequate tool to study physiological responses of rat $5-\mathrm{HT}_{1 \mathrm{~A}}$ receptors, although not being more selective than the agonists of the azapirone class. In humans, however, only the plasma growth hormone response can be attributed to a $5-\mathrm{HT}_{1 \mathrm{~A}}$ receptor activity. However, ergotamine seems to modulate 5-HT release by means of a 5-HT receptor which is not of 5- $\mathrm{HT}_{1 \mathrm{~B} / 1 \mathrm{D}}$ subtype.

\section{REFERENCES}

Aghajanian GK (1978): Feedback regulation of central monoaminergic neurons: Evidence from single-cell recording studies. In Youdim $\mathrm{MBH}$, Lovenbery $\mathrm{W}$, Sharman DF, Lagnado JR (eds), Essays in Neurochemistry and Neuropharmacology. New York, Wiley, pp 1-32

Aghajanian GK, Lakoski JM (1984): Hyperpolarization of serotonergic neurons by serotonin and LSD: Studies in brain slices showing increased $\mathrm{K}+$ conductance. Brain Res 305:181-185

Anderson IM, Cowen PJ, Grahame-Smith DG (1990): The effects of gepirone on neuroendocrine function and temperature in humans. Psychopharmacology 100:498-503

Anderson IM, Cowen PJ (1992): Effect of pindolol on endocrine and temperature responses to buspirone in healthy volunteers. Psychopharmacology 106:428-432

Andrade R, Nicoll RA (1987): Novel anxiolytics discriminate between postsynaptic serotonin receptors meditating different physiological responses on single neurons of the rat hippocampus. Naunyn-Schmiedeberg's Arch Pharmacol 336:5-10

Aulakh CA, Wozniak KM, Hass M, Hill JL, Zohar J, Murphy DL (1988): Food intake, neuroendocrine, and temperature effects of 8-OH-DPAT in in the rat. Eur J Pharmacol 146:253-259
Badia A, Moron A, Cuff L, Vila E (1988): Effects of ergotamine on cardiovascular catecholamine receptors in the pithed rat. Gen Pharmac 19:475-481

Benkelfat C (1993): Serotonergic mechanisms in psychiatric disorders: New research tools, new ideas. Int Clin Psychopharmacol 8:53-56

Blier P, Ramdine R, Galzin AM, Langer SZ (1989): Frequencydependence of serotonin autoreceptor but not alpha 2-adrenoceptor inhibition of [3H]-serotonin release in rat hypothalamic slices. Naunyn-Schmiedeberg's Arch Pharmacol 339:60-64

Blier P, de Montigny C, Chaput Y (1990): A role for the serotonin system in the mechanism of action of antidepressant treatments: Preclinical evidence. J Clin Psychiat 51:14-20

Blier P, de Montigny C (1987): Modification of 5-HT neuron properties by sustained administration of the 5-HT1A agonist gepirone: Electrophysiological studies in the rat brain. Synapse 1:470-480

Blier P, de Montigny C (1990): Differential effect of gepirone on presynaptic and postsynaptic serotonin receptors: Single-cell recording studies. J Clin Psychopharmacol 10:13S-20S

Blier P, de Montigny C (1994): Current advances and trends in the treatment of depression. Trends Pharmacol Sci 15:220-226

Blier P, Seletti B, Young S, Benkelfat C, de Montigny C (1994): Serotonin $_{1 \mathrm{~A}}$ receptor activation and hypothermia: Evidence for a postsynaptic mechanism in humans. Neuropsychopharmacology 10:99S

Boess FG, Martin IL (1994): Molecular biology of 5-HT receptors. Neuropharmacology 33:275-317

Brunel S, de Montigny C (1987): Diurnal rhythms in the responsiveness of hippocampal pyramidal neurons to serotonin, norepinephrine, gamma-aminobutiric acid, and acetylcholine. Brain Res Bull 18:205-212

Chaput Y, Blier P, de Montigny C (1986): In vivo electrophysiological evidence for the regulatory role of autoreceptors on serotoninergic terminals. J Neurosci 6:2796-2801

Chaput Y, de Montigny C (1988): Effects of the $5-\mathrm{HT}_{1}$ receptor antagonist BMY 7378 on the 5-HT neurotransmission: Electrophysiological studies in the rat central nervous system. J Pharmacol Exp Ther 246:359-370

Cowen PJ, Anderson IM, Grahame-Smith DG (1990): Neuroendocrine effects of azapirones. J Clin Psychopharmacol 10:21S-25S

Dong J, de Montigny C, Blier P (1997): Effect of acute versus sustained administration of the $5-\mathrm{HT}_{1 \mathrm{~A}}$ receptor agonist ipsapirone: Electrophysiological studies in rat hippocampus and dorsal raphe. Naunyn-Schmiedeberg's Arch Pharmacol 356:303-311

El Mansari M, Blier P (1996): Functional characterization of $5-\mathrm{HT}_{1 \mathrm{D}}$ receptors on the modulation of 5-HT release in guinea pig mesencephalic raphe, hippocampus, and frontal cortex. Br J Pharmacol 118:681-689

Erlander MG, Lovenbery TW, Baron BM, De Lecea L, Danielson PE, Racke M, Slone AL, Siegel BW, Foye PE, Cannon K, Burns JE, Sutcliffe JG (1993): Two members of distinct subfamily of 5-hydroxytryptamine receptors differentially expressed in rat brain. Proc Natl Acad Sci USA 90:3452-3456 
Feuerstein TJ, Lupp A, Hertting G (1987): The serotonin (5HT) autoreceptor in the hippocampus of the rabbit: Role of 5-HT biophase concentration. Neuropharmacology 26:1071-1080

Fletcher A, Bill DJ, Bill SJ, Cliffe IA, Dover GM, Forster EA, Haskins JT, Jones D, Mansell HL, Reilly Y (1994): WAY 100135: A novel, selective antagonist at presynaptic and postsynaptic 5- $\mathrm{HT}_{1 \mathrm{~A}}$ receptors. Eur J Pharmacol 237:283291

Fletcher A, Forster EA, Brown G, Cliffe IA, Hartley JE, Jones DE, McLenachan A, Stanhope KJ, Critchley DJP, Childs KJ, Middlefell VC, Lanfumey L, Corradeti R, Laporte A-M, Gozlan H, Hamon M, Dourish CT (1996): Electrophysiological, biochemical, neurohormonal and behavioural studies with WAY-100635, a potent, selective and silent 5- $\mathrm{HT}_{1 \mathrm{~A}}$ receptor antagonist. Behav Brain Res 73:337-353

Fleiss JL (1986): The Design of Analysis of Clinical Experiments. New York, Wiley

Godbout R, Chaput Y, Blier P, de Montigny C (1991): Tandospirone and its metabolite, 1-(2-pyrimidinyl)-piperazine-I. Effects of acute and long-term administration of tandospirone on serotonin neurotransmission. Neuropharmacology 30:679-690

Goodman LS, Gilman A (1985): The Pharmacological Basis of Therapeutics, 7th ed. New York/London, MacMillan, p 931

Göthert M, Weinheimer G (1979): Extracellular 5-hydroxytryptamine inhibits 5-hydroxytryptamine release from rat brain cortex slices. Naunyn-Schmiedeberg's Arch Pharmacol 310:93-96

Gudelsky GA, Koenig JI, Meltzer HY (1988): Involvement of serotonergic receptor subtypes in thermoregulatory responses. In Rech RH, Gudelsky GA (eds), 5-HT agonists as psychoactive drugs. Ann Arbor, MI, NPP Books, pp 127-142

Gundlach AL, Krstich M, Beart PM (1983): Guanine nucleotides reveal differential actions of ergot derivatives at D-2 receptors labeled by $\left[{ }^{3} \mathrm{H}\right]$ spiperone in striatal homogenates. Brain Res 278:155-163

Haddjeri N, Blier P (1995): Pre- and post-synaptic effects of the $5-\mathrm{HT}_{3}$ agonist 2-methyl-5-HT on the 5-HT system in the rat brain. Synapse 20:54-67

Hadrava V, Blier P, Dennis T, Ortemann C, de Montigny C (1995): Characterization of 5-Hydroxytryptamine A $_{\mathrm{A}}$ properties of flesinoxan: In vivo electrophysiology and hypothermia study. Neuropharmacology 34:1311-1326

Kandel ER, Spencer WA (1961): Electrophysiology of hippocampal neurons. II. After potentials and repetitive firing. J Neurophysiol 24:243-259

Langer SZ, Schoemaker H (1986): High affinity by ergotamine of $\left[{ }^{3} \mathrm{H}\right]-8-\mathrm{OH}-\mathrm{DPAT}$ binding to hippocampal $5-\mathrm{HT}_{1 \mathrm{~A}}$ receptors. Br J Pharmacol 89:475

Lesch KP, Rupprecht R, Poten B, Muller U, Sohnle K, Fritze J, Schulte HM (1989): Endocrine responses to $5-\mathrm{HT}_{1 \mathrm{~A}}$ receptor activation by ipsapirone in humans. Biol Psychiat 26:203-205

Lesch KP, Mayer S, Disselkamp-Tietze J, Hoh A, Schoellnhammer G, Schulte HM (1990a): Subsensitivity of the 5-hydroxytryptamine 1A (5-HT1A) receptor-mediated hypothermic response to ipsapirone in unipolar depression. Life Sci 46:1271-1277
Lesch KP, Mayer S, Disselkamp-Tietze J, Hoh A, Wiesmann M, Osterheider M, Schulte HM (1990b): 5-HT1A receptor responsivity in unipolar depression. Evaluation of ipsapirone-induced ACTH and cortisol secretion in patients and controls. Biol Psychiat 28:620-628

Lesch KP, Poten B, Sohnle K, Schulte HM (1990c): Pharmacology of the hypothermic response to 5-HT1A receptor activation in humans. Eur J Clin Pharmacol 39:17-19

Lesch KP, Sohnle K, Poten B, Schoellnhammer G, Rupprecht R, Schulte, HM (1990d): Corticotropin and cortisol secretion after central 5-hydroxytryptamine-1A (5-HT1A) receptor activation: Effects of 5-HT receptor and betaadrenoceptor antagonists. J Clin Endrocrinol Metab 70:670-674

Lovenberg TW, Baron BM, De Lecea L, Miller JD, Prosser RA, Rea MA, Foye PE, Racke M, Slone AL, Siegel BW, et al. (1993): A novel adenylyl cyclase-activating serotonin receptor (5-HT7) implicated in the regulation of mammalian circadian rhythms. Neuron 11:449-458

Maura G, Ulivi M, Raiteri M (1987): (-)-Propranolol and $(+/-)$-cyanopindolol are mixed agonists-antagonists at serotonin autoreceptors in the hippocampus of the rat brain. Neuropharmacology 26:713-717

McPherson GA, Beart PM (1983): The selectivity of some ergot derivatives for $\alpha 1$ - and $\alpha 2$-adrenoceptors of rat cerebral cortex. Eur J Pharmacol 91:363-369

Meltzer HY, Flemming R, Robertson A (1983): The effect of buspirone on prolactin and growth hormone secretion in man. Arch Gen Psychiat 40:1099-1102

Meltzer HY, Maes M (1996): Effect of pindolol on hormone secretion and body temperature: Partial agonist effects. J Neural Transm 103:77-88

Millan MJ, Rivet JM, Canton H, Le Marouille-Girardon S, Gobert A (1993): Induction of hypothermia as a model of 5-hydroxytryptamine $1 \mathrm{~A}$ receptor-mediated activity in the rat: A pharmacological characterization of the actions of novel agonists and antagonists. J Pharmacol Exp Ther 264:1364-1376

Miller HL, Delgado PL, Fischette CT, Seibyl J, Krystal JH, Charney DS (1990): Neuroendocrine effects of tandospirone (SM-3997) in healthy subjects. Am C Neuropsychopharmacol 29:191

Piñeyro G, Castanon N, Hen R, Blier P (1995): Regulation of $[3 \mathrm{H}] 5-\mathrm{HT}$ release in raphe, frontal cortex, and hippocampus of 5-HT1B knock-out mice. NeuroReport 7:353359

Ranck JB (1975): Behavioral correlates and firing repertoires of neurons in the dorsal hippocampal formation and septum of unrestrained rats. In Isaacson RL, Pribram KH (eds), The Hippocampus, NY, pp 207-244

Seletti B, Benkelfat C, Blier P, Annable L, Gilbert F, de Montigny C (1995): Serotonin, receptor activation by flesinoxan in humans-Body temperature and neuroendocrine responses. Neuropsychopharmacology 13:93104

Shiah I-S, Yatham LN, Lam RW, Zis AP (1997): Effects of valproate on $5-\mathrm{HT}_{1 \mathrm{~A}}$ receptor function in humans. Biol Psychiat 41:207

Silberstein SD (1997): The pharmacology of ergotamine and dihydroergotamine. Neurology 37:S15-S25

Silberstein SD, Young WB (1995): Safety and efficacy of 
ergotamine tartrate and dihydroergotamine in the treatment of migraine and status migrainosus. Neurology 45:577-584

Spitzer RL, Williams JBW, Gibbon M, First MB (1992): The structured clinical interview for DSM-III-R (SCID), I: History, rationale, and description. Arch Gen Psychiat 49:624-629
Tfelt-Hansen P, Johnson ES (1993): Ergotamine. In TfeltHansen P, Welch KMA (eds), The Headaches. New York, Raven Press, pp 313-322

Wozniak KM, Aulakh CS, Hill JL, Murphy DL (1988): The effect of 8-OH-DPAT on temperature in the rat and its modification by chronic antidepressant treatments. Pharmacol Biochem Behav 30:451-456 